\title{
La teoría del amor en el pensamiento de Ortega a la altura de 1914. Claves ético-filosóficas y antropológicas de Meditaciones del Quijote ${ }^{1}$
}

\author{
Alejandro de Haro Honrubia ${ }^{2}$
}

Recibido: 02 de septiembre de 2016 / Aceptado: 05 de junio de 2017

Resumen. Este artículo científico tiene como principal objetivo ofrecer las claves ético-filosóficas y antropológicas de Meditaciones del Quijote (1914). Para lograr tal fin, recurriremos a la teoría del amor que Ortega, siguiendo toda una tradición, elabora y que vertebra su primera gran obra. Ortega meditó, y mucho, sobre el amor. El eterno insatisfecho, como Ortega define el amor en Estudios sobre el amor (1941) recorre sus páginas desde sus inicios hasta el final de su producción, pues no en vano Ortega fue un filósofo, siendo para él la filosofía, como ya aclara desde 1914, la ciencia general del amor; dentro del globo intelectual representa el mayor ímpetu hacia una omnímoda conexión. Justificamos la elaboración de este trabajo en el hecho de que su reflexión sobre el amor y también el odio no se ha estudiado atendiendo a la teoría ético-filosófica y antropológica contenida en Meditaciones del Quijote, en el contexto de la cual Ortega dialoga con autores como Sócrates o Platón, Spinoza, Nietzsche o Scheler. Nos ocuparemos asimismo de las interferencias político-sociales de su meditación sobre el amor en la España de la Restauración.

Palabras clave: amor; antropología; ética; filosofía; odio; Ortega; valores.

\section{[en] The theory of love in Ortega's thought about 1914. Ethical-philosophical and anthropological keys of Meditations on Quixote}

\begin{abstract}
In the following pages, I am going to put forward the ethical-philosophical and anthropological keys of Meditations on Quixote (1914). In order to do that, we pay attention to the theory of love in Ortega's thought in the context of his first and quoted work. Ortega thought carefully about the love following an important philosophical tradition which dates back to classical times in Greece. Ortega was a philosopher and for this particular reason he considered that philosophy is the general science of love; inside the intelectual globe, that represents the great impetus towards an absolute connexion. We try to justify this work in the fact that Ortega's thought about love and hatred hasn't been studied taking into account the ethical-philosophical and anthropological theory that appers in Meditation on Quixote. Likewise, it is true that Ortega dialogues, in the contexto of that work, with other authors, such as Sócrates, Plato, Spinoza, Nietzsche or Scheler. We will also study the social and political interferences of his reflection on love in the restoration of the Spanish monarchy.
\end{abstract}

Keywords: love; anthropology; ethic; philosophy; hate; Ortega; values.

1 Este artículo se finalizó en el marco del Proyecto de investigación, "Redes intelectuales y de socialización y transferencia culturales. Ortega y Gasset como catalizador cultural en España, Europa y América”, que dirige el profesor José Varela Ortega, y que tiene la siguiente referencia FFI2013-48725-C2-1-P. Agradezco las facilidades que siempre me han brindado desde la Fundación José Ortega y Gasset/Gregorio Marañón de Madrid en mis tareas de investigación.

2 Universidad de Castilla-La Mancha Alejandro.Haro@uclm.es ORCID: 0000-0003-1936-3920 
Sumario. 1. Presentación y justificación de la elección del tema. La teoría del amor en Meditaciones del Quijote (1914) como solución al problema español; 2. Fuentes clásicas en la reflexión orteguiana sobre el amor a la altura de 1914. Más allá de Cervantes y El Quijote. La filosofía de Sócrates y Platón; 3. Amor y odio en la teoría ético filosófica de Meditaciones de Quijote. Interferencias político sociales del fenómeno del amor en la España de la Restauración; 4. Algunas otras fuentes en la teoría orteguiana del amor. La ética de las pasiones/afectos de Spinoza y la fenomenología del amor de Scheler como referentes de excepción; 5. Resultados de la investigación y breve conclusión; 6 . Referencias bibliográficas.

Cómo citar: Haro Honrubia, A. (2018): "La teoría del amor en el pensamiento de Ortega a la altura de 1914. Claves ético-filosóficas y antropológicas de Meditaciones del Quijote", en Revista Anales del Seminario de Historia de la Filosofía 35 (1), 175-204.

Cada día me interesa menos sentenciar: a ser juez de las cosas, voy prefiriendo ser su amante (Meditaciones del Quijote, OC, I, 759).

\section{Presentación y justificación de la elección del tema. La teoría del amor en Meditaciones del Quijote (1914) como solución al problema español}

Este artículo versa sobre la antropología filosófica y la reflexión ética que en torno al problema del amor - con una larga tradición en la historia del pensamiento filosófico occidental desde que los griegos la inauguraran veinticinco siglo atrás- podemos encontrar en la obra temprana de Ortega en torno a la programática fecha de 1914 -año en que se publican sus Meditaciones del Quijote-, aun cuando también se apuntan algunas conexiones tanto con su pensamiento inicial de mocedad como de madurez intelectual.

Por antropología filosófica sobre el amor, entendemos en este trabajo de investigación, la meditación -en este caso en relación a la obra de Ortega- sobre aquél como elemento constitutivo del individuo, en cuya alma o espíritu pugnan el odio y el amor -cuya dimensión ética, la de este último, responde a su afán de comprensión, concordia y conexión-, dependiendo la intensidad de esta lucha de las diferentes situaciones que cada individuo como persona experimente en lo que sería su biografía o conjunto de experiencias vividas, pues como dice Ortega en 1930: "el sentido primario y radical de la palabra vida, aparece cuando se la emplea en el sentido de biografía y no en el de biología"3.

Ortega también remite el amor y el odio al ámbito de la psique, entendiendo aquellos dos como impulsos originarios de ésta: "funciones espontáneas de la psique" que "son la raíz de la existencia personal"4.

¿Cuál es, según Ortega, nuestra posición ante el "amor” como elemento sobre el cual se ha teorizado desde que el ser humano ha sido capaz de reflexión? En amor, dice el filósofo español en Meditación de nuestro tiempo. Introducción al presente (1928), "todos son sabios a nativitate, todos creen poseer la clave secreta de su arcana sustancia. Todos: ellos y ellas". Porque es raro encontrar un hombre, continúa

\footnotetext{
3 La rebelión de las masas, OC, IV, 422, n. Las citas de las obras de José Ortega y Gasset remiten a la edición de Obras Completas, Madrid, Taurus/Fundación José Ortega y Gasset, 2004. Al título del escrito sigue en números romanos el tomo y en arábigos la (s) página (s)).

4 J. Ortega y Gasset. Ensayos filosóficos. Biología y pedagogía, OC, II, 405.
} 
diciendo Ortega, que paladina o tácitamente "no crea ser un Don Juan, o haberlo sido, o -lo que es peor todavía- no crea haberlo podido ser si hubiese querido. Cayendo en un inocente quid pro quo, ya que Don Juan en persona no entiende nada de amor: su papel es hacerlo, no definirlo. Al que ha empleado su tiempo en meditar sobre el amor, no le suele quedar mucho para practicarlo"s.

Al menos todos aquellos que nos dedicamos desde hace años al estudio de su pensamiento, sabemos que Ortega meditó, y mucho, sobre el amor. El eterno insatisfecho, como Ortega define el amor en Estudios sobre el amor (1941) recorre sus páginas desde sus inicios hasta el final de su producción, pues no en vano Ortega fue un filósofo, siendo para él la filosofía, como ya declara en 1914, "la ciencia general del amor; dentro del globo intelectual representa el mayor ímpetu hacia una omnímoda conexión"6.

En "Glosas", publicado en Vida Nueva, el 1 de diciembre de 1902, Ortega se refiere por vez primera al amor en su oposición al odio que casi siempre acompañará al primero en su reflexión, pues como dice el filósofo español en ¿Qué es la ciencia, qué la filosofía? (1928): "en cada concepto colabora su antagonista y que sólo está completo junto con el otro"'. Y así, como digo, ocurre desde sus primeros trabajos en relación al odio y el amor que son aquí el objeto de nuestra investigación: "Así - dice Ortega en 1902- las palabras son creídas; así se hacen rebotar en el tiempo y en el espacio los grandes amores y los grandes odios"

Aunque su meditación sobre el amor, como ocurre con la mayoría de las temáticas por Ortega estudiadas, responde a la evolución de su pensamiento, en las siguientes páginas abordaremos esta cuestión en el contexto de su primera -y ya mentadagran obra, Meditaciones del Quijote (1914) ${ }^{9}$, donde Ortega, inspirado por filosóficos deseos y siempre a la altura de los tiempos, reflexiona sobre el denominado problema español que no solamente es un problema político e histórico, sino que también

5 Meditación de nuestro tiempo. Introducción al presente, OC, VIII, 35-36. El mito de Don Juan no puede ser desarrollado aquí por cuestiones de espacio, pero remito a dos bellos libros escritos por el profesor José Lasaga: Las metamorfosis del seductor. Ensayo sobre el mito de Don Juan, Madrid, Síntesis, 2004; y Figuras de la vida buena (Ensayo sobre las ideas morales de Ortega y Gasset), Madrid, Enigma Editores, 2006.

Meditaciones del Quijote, OC, I, 752.

¿Qué es la ciencia, qué la filosofía?, OC, VIII, 165.

Glosas, OC, I, 8.

9 Véanse, para conocer el proceso de elaboración de la primera obra de Ortega, las "Notas de trabajo de Meditaciones del Quijote", ed. de Isabel Ferreiro Lavedán y Felipe González Alcázar, Revista de Estudios Orteguianos, n. ${ }^{\circ} 28$ (2014), pp. 17-41. Algunos otros trabajos que tratan el tema del amor en la obra de Ortega son los siguientes: Campomar Fornieles, M. "Victoria Ocampo en la cultura del amor de Ortega y Gasset". Revista de Estudios Orteguianos, n ${ }^{\circ}$ 3, 2001, pp. 209-290. Carchidi, L. "Estudios sobre el amor. Radici letterarie e filosofiche del tema dell'amore in José Ortega y Gasset”. Atti del XX Convegno [Associazione Ispanisti Italiani] / Domenico Antonio Cusato, Loretta Frattale (Coord.), Vol. 1, 2002 (La penna di venere: escritture dell'ammore nelle culture iberiche), pp. 71-80; Berges, C.: "Stendhal, Ortega y el amor". Insula. Revista de Letras y ciencias humanas, $n^{\circ}$ s 438-439, 1983, p. 5; Ferreiro Lavedán, M. I. "El amor por lo distinto en la obra de Ortega y Gasset”. Razón Española: Revista bimestral de pensamiento, n 133, 2005, pp. 181-202; De Salas, J. “Amor Intellectualis. Spinoza en la configuración de la obra de Ortega y algunas posibles fuentes de la obra temprana del filósofo español”. En Atilano Domínguez (Coord.): Spinoza y España, Actas del Congreso Internacional sobre Relaciones entre Spinoza y España, Ediciones de la UCLM, 1994, pp. 285-293; Gonzalo Gironés, G. "Hablando con Ortega acerca del amor". Anales Valentinos: revista de filosofía y teología. Vol. 30, $\mathrm{n}^{\circ}$ 60, 2004, p. 289; Laín Entralgo, P. “Ciencia, esperanza y amor en el pensamiento de Ortega”. Javier San Martin (Coord.): Ortega y la fenomenología: Actas de la I Semana Española de Fenomenología, 1992, pp. $325-$ 338. González-Sandoval Buedo, J. "Sobre el amor en Ortega". Revista de Estudios Orteguianos, n 22, 2011 , pp. 197-228; Ramos de la Torre, L. "Vida y salvación desde al amor a las cosas en Claudio Rodríguez y Ortega". Duererías (Ejemplar dedicado a "Brevis e absurda: vita"), nº 5, 2005, pp. 108-151. 
se hace sentir con fuerza en el orden de las ideas o intelectual -"la decadencia española consiste pura y simplemente en falta de ciencia, en privación de teoría", dice Ortega en 1911- y especialmente en el ámbito social convivencial, al haberse apoderado del individuo medio español el odio, el resentimiento y el rencor. Ortega recurre a este propósito, aunque nos diga que dejó tiempo atrás la "zona tórrida de Nietzsche", a la teoría del filósofo alemán cuando dice en Meditaciones del Quijote que "con aguda mirada, ya había Nietzsche descubierto en ciertas actitudes morales formas y productos del rencor" $"$. Odio o rencor que han anulado al amor, abocando al individuo y la sociedad que aquél habita a una -si no se corrige tal situacióncompleta destrucción.

Lo que Ortega propone con el fin de solventar esta situación, siendo ésta nuestra hipótesis de trabajo, es que el amor, elemento central en su meditación, vuelva a gobernar el universo y por extensión los corazones o morada íntima de los españoles, pues amor es conexión, dice Ortega inspirado, como veremos, por el pensamiento clásico griego (Sócrates y Platón), frente al odio que es inconexión y aniquilamiento - como afirma también Spinoza en la Parte Tercera de su Ética. Del origen y naturaleza de los afectos y a quien Ortega leyó-, afectando al orden de los valores o vertiente estimativa (Max Scheler) que es primordial para Ortega desde los inicios de su producción.

Justificamos la elaboración de este trabajo en el hecho de que su reflexión sobre el amor y el odio no se ha estudiado atendiendo detenidamente a la teoría éticofilosófico y antropológica contenida en Meditaciones del Quijote, en el contexto de la cual Ortega dialoga con diversas figuras clave del ámbito intelectual como los ya mencionados Sócrates y Platón, en lo que denominamos las fuentes clásicas de su pensamiento a propósito del amor, pero también intercambia ideas con otros autores también referidos anteriormente, y a quienes Ortega siguió: Spinoza, Nietzsche o Scheler ${ }^{11}$.

Nos ocuparemos asimismo, atendiendo a lo que sería la estructura de este trabajo, de las interferencias político-sociales de su meditación sobre el amor en la España de la Restauración que se encuentra, para Ortega, en el epicentro del problema de nuestra nación, pues, según el filósofo español,

perdiose en la Restauración la sensibilidad para todo lo verdaderamente fuerte, excelso, plenario y profundo (...). Fue, como Nietzsche diría, una etapa de perversión en los instintos valoradores. Lo grande no se sentía como grande; lo puro no sobrecogía los corazones; la calidad de perfección y excelsitud era invisible para aquellos hombres (...). $\mathrm{Y}$ fatalmente lo mediocre y liviano pareció aumentar su densidad ${ }^{12}$.

10 Meditaciones del Quijote, O.C, I, 750. Ortega evidencia en sus Obras completas que fue un entusiasta lector de Nietzsche.

11 De Spinoza a Ortega le interesa su teoría del "amor intellectualis", aun cuando también encontramos conexiones con su reflexión sobre el odio y el amor. De Max Scheler, a Ortega le atrae su filosofía de los valores, así como también encontramos ciertas vinculaciones del pensamiento de Ortega con la fenomenología del amor y el odio o gramática de los sentimientos (“ordo amoris” la llama Max Scheler) del filósofo alemán. De Nietzsche, Ortega refiere en varias partes de su obra la teoría del aquél sobre el odio en forma de resentimiento y rencor, así como también es importante la advertencia de Ortega en relación a una de las mayores perversiones y que auxiliado por Nietzsche denunció: la perversión en los instintos valoradores, cuyo apogeo dice Ortega lo encontramos en la época conocida como Restauración, régimen que auspició que el tipo medio español sometiera los valores superiores a aquellos de más baja condición revelando la grave enfermedad de su función estimativa, como dirá Ortega en su obra posterior.

12 Meditaciones del Quijote, O.C, I, 772. 
Esta situación de mediocridad y achabacanamiento nacional que denuncia Ortega en sus páginas, nos hace pensar que la preocupación de aquél por el devenir de España responde también a una preocupación de carácter intelectual o filosófico, pues no en vano dice Ortega -en concreto en 1908 en su trabajo La conservación de la cultura - que por el alma de España "no han pasado ni Platón ni Newton ni Kant, y con una terquedad incomprensible viene cometiendo, desde hace tres siglos, el gran pecado contra el Espíritu Santo: la incultura, el horror a las ideas y a las teorías"13.

El problema de España lo es de carácter histórico-social pero también es un problema filosófico que responde a la ausencia de Modernidad -como sinónimo de ciencia-, de "amor" por la cultura moderna, que es una cultura conceptual o de ideas, o lo que es igual, una cultura de las profundidades, dirá también el joven Ortega. Lo que se impone, por el contrario, es un exceso de cultura material o de las superficies, un desorbitado predominio de la sensualidad/ impresión, obstaculizando el ejercicio de la razón. No es de extrañar que en 1914 diga el filósofo español lo siguiente:

Representamos en el mapa moral de Europa, el extremo predominio de la impresión. El concepto no ha sido nunca nuestro elemento. No hay duda que seríamos infieles a nuestro destino si abandonáramos la enérgica afirmación de impresionismo yacente en nuestro pasado. Yo no propongo ningún abandono, sino todo lo contrario: una integración ${ }^{14}$.

Ortega no propone ninguna exclusión -se trataría, como dice aquél recordando a Renán, de "excluir toda exclusión"-, sino más bien y en sintonía con el espíritu clásico griego -lo clásico es "lo que no ha pasado ni ha muerto"15-, en el que aquél se cobija en su juventud, una nueva integración entre concepto, pensamiento o razón (pathos trascendental o del Norte) e impresión (pathos materialista o del Sur), que favorecería la comprensión -el afán de comprensión como actividad de amor dice Ortega- en lo que sería un nuevo régimen de salud, pues: "La salud es la liberación de todo pathos, la superación de todas las fórmulas inestables y excéntricas" ${ }^{16}$. Aun buscando un equilibrio, este no deja de ser inestable, en la medida en que Ortega privilegia en estos momentos, al menos a nivel intelectual, en torno a la programática fecha de 1914, la labor del concepto como sinónimo de labor de cultura, pues "la cultura no es la vida toda, sino solo el momento de seguridad, de firmeza, de claridad"17, siendo el concepto un instrumento, "no para sustituir la espontaneidad vital, sino para asegurarla"18.

13 La conservación de la cultura, $\mathrm{OC}, \mathrm{I}, 152$.

14 Meditaciones del Quijote, OC, I, 790.

15 Una respuesta a una pregunta, OC, I, 467. Lo clásico es lo que lleva en sí "el perpetuo manadero elemental de las energías espirituales, lleva en sí la fuente de la vida" (Una respuesta a una pregunta, OC, I, 467). Sólo ha habido en el mundo, dice Ortega, "una cultura clásica, por la sencilla razón de que hay sólo una cultura verdadera - una sola aritmética, una sola física, una sola lógica, una sola ética- y ésta, evidentemente, nació sólo una vez. Sólo Grecia no es un pasado: Demócrito y Platón, Esquilo y Aristófanes, Euclides y Arquímedes, viven hoy, son tan actuales y presentes como en su edad" (Problemas culturales.- Sobre la enseñanza clásica, OC, I, 471-472).

16 Arte de este mundo y del otro, OC, I, 436.

17 Cultura, dice Ortega, "es lo firme frente a lo vacilante, es lo fijo frente a lo huidero, es lo claro frente a lo oscuro" (Meditaciones del Quijote, OC, I, 786).

18 Meditaciones del Quijote, OC, I, 786. El concepto "no puede ser como una nueva cosa sutil destinada a suplantar las cosas materiales". La misión del concepto "no estriba, pues, en desalojar la intuición, la impresión real. La razón no puede, no tiene que aspirar a sustituir la vida. Esta misma oposición, tan usada hoy por los que no quieren trabajar, entre la razón y la vida es ya sospechosa. ¡Como si la razón no fuera una función vital 
La importancia concedida al concepto a la altura de 1914 como elemento que confiere consistencia/claridad intelectual al caos de la realidad vital, revela, a mi juicio, los restos que aún quedan en su pensamiento del intelectualismo/idealismo en que estuvo sumido Ortega en su mocedad y que éste se ha propuso superar -lo que los estudiosos de su pensamiento entendemos como la superación de la modernidad en Ortega- (si bien toda superación es negación, toda negación es también conservación, recuerda Ortega con la mirada puesta en Hegel ${ }^{19}$ desde 1912 -aunque existen indicios un poco más atrás en que afirma el primado de lo vital- que es cuando comienza a estudiar en serio fenomenología y a interesarse por el mundo de la vida (Lebenswelt): "La fenomenología exige que el mundo como realidad cósmica sea llevado a mi realidad vital, que es la manera, dice el profesor San Martín, de que el mundo haya de implicar la perspectiva. El mundo implica el modo de darse. Pues bien no es otra cosa la llamada reducción fenomenológica, que es la puerta de entrada en el nuevo continente" 20 .

En Meditaciones del Quijote observamos la deuda de Ortega con la fenomenología, aunque como dice el profesor Javier San Martin, sin hacer aquél ninguna concesión terminológica al nuevo movimiento ${ }^{21}$. La fenomenología del mundo de la vida, aquella que se interesa por las cosas mismas, incorpora en el pensamiento de Ortega la idea del amor (fenomenología del amor): “iSantificadas sean las cosas! ¡Amadlas, amadlas! Cada cosa es un hada que reviste de miseria y vulgaridad sus tesoros interiores, y es una virgen que ha de ser enamorada para hacerse fecunda" 22 . Fecundidad que consiste en conducir aquéllas a su máximo esplendor o significación, donde las cosas revelan su sentido que no es otro que su máximo valor y conexión con el resto de elementos o cosas que conforman el universo cuyo orden responde a la acción benefactora del amor:

El «sentido» de una cosa es la forma suprema de su coexistencia con las demás, es su dimensión de profundidad. No, no me basta con tener la materialidad de una cosa, necesito, además, conocer el «sentido» que tiene, es decir, la sombra mística que sobre ella vierte el resto del universo. Preguntémonos por el sentido de las cosas, o lo que es lo mismo, hagamos de cada una el centro virtual del mundo. Pero, ¿no es esto lo que hace el amor? Decir de un objeto que lo amamos y decir que es para nosotros centro del universo, lugar donde se anudan los hilos todos cuya trama es nuestra vida, nuestro mundo, ¿no son expresiones equivalentes? ¡Ah! Sin duda, sin duda ${ }^{23}$.

y espontánea del mismo linaje que el ver o el palpar!” (Meditaciones del Quijote, OC, I, 784).

19 Véase de José Ortega y Gasset, "Hegel. Notas de trabajo”, edición de Domingo Hernández Sánchez, Fundación José Ortega y Gasset/Abada Editores, 2007. Dice Ortega: "Hegel vio muy bien que en todo lo vivo -la idea o la carne- superar es negar; pero negar es conservar" (El Quijote en la escuela, OC, II, 424).

20 J. San Martín. La fenomenología de Ortega y Gasset, Madrid, Biblioteca Nueva, 2012, p. 95 . Ortega desde 1912 aproximadamente se ha propuesto superar la modernidad filosófica que el pensador español identifica con las ideas de racionalismo e idealismo (subjetivismo), si bien es verdad que lo moderno como sinónimo de ciencia y teoría, o las virtudes intelectuales del concepto, le seguirá atrayendo.

21 Por ello dice Javier San Martin, que "su interpretación ha sido un tanto errática" (Véase "La fenomenología en Meditaciones del Quijote: Textos de 1914”, en ibid., p. 86).

22 Meditaciones del Quijote, OC, I, 747-748. Superado el neokantismo y desde la fenomenología, Ortega se decanta progresivamente por el primado de la vida, -no es vivir con orden es vivir primero, dirá en 1914-, cuyo lema es el amor que en el pensamiento de Ortega simboliza, como ya apuntamos en el cuerpo del texto, lo que Renán decía y recuerda Ortega con posterioridad: “excluir toda exclusión” (España Invertebrada, OC, III, 459).

23 Meditaciones del Quijote, OC, I, 782. 
Pero antes de arribar al nuevo continente de la fenomenología con su lema de "vuelta a las cosas mismas"24, a esas que según Ortega hay que santificar y amar, éste consagró su juventud al reino del ideal, pues como dice él mismo en 1906, "la mocedad es siempre idealista", pues en ella "al mundo que es oponemos un mundo que debe ser. Sobre la realidad trabajamos por fundar la idealidad"25. Pero el idealismo cederá progresivamente a una especie, como yo mismo lo denomino, de "vitalismo perspectivista" a partir de 1910, cuando Ortega diga en Adán en el paraíso lo siguiente: "Para Adán la vida existe como problema (...). Esto es el hombre: el problema en la vida", así como también dice Ortega en ese trabajo de la temprana fecha de 1910 que "hay tantas realidades como puntos de vista"26.

Más adelante, en Arte de este mundo y del otro (1911) Ortega afirma que "la religión y la poesía son para la vida" ${ }^{27}$, mostrando a partir de entonces la prioridad que en su pensamiento, en un sentido global, alcanzará lo vital que encuentra en la razón -destacando del concepto su potencialidad- un instrumento de que servirse en su búsqueda de orientación y seguridad.

Estos cambios en su filosofía, el paso del idealismo al vitalismo y realismo fenomenológico ${ }^{28}$, interfieren, como ya indiqué anteriormente, en su reflexión sobre el amor -del amor al ideal al amor a la realidad de las cosas en su más absoluta circunstancialidad o mundanidad vital-.

Sus referencias desde 1909 al amor intellectualis, - "este amor a la verdad, que se contenta con ver, es una acción pura, intelectual, algo así como lo que llamaba Spinoza amor intellectualis Dei"29- que intensifica en 1914 en Meditaciones del Quijote -en relación al problema español- y su posterior distanciamiento de esta expresión y su significación más intelectualista en su obra tardía confirman una de mis convicciones sobre la obra del filósofo español, a saber: que los cambios en

24 Según Ortega "al lado de gloriosos asuntos, se habla muy frecuentemente en estas Meditaciones de las cosas más nimias. Se atiende a detalles del paisaje español, del modo de conversar de los labriegos, del giro de las danzas y cantos populares, de los colores y estilos en el traje y en los utensilios, de las peculiaridades del idioma, $\mathrm{y}$, en general, de las manifestaciones menudas donde se revela la intimidad de una raza" (Meditaciones del Quijote, OC, I, 753-754).

25 Canto a los muertos, a los deberes y a los ideales, O.C, I, 107. Ortega se distancia de cualquier utopismo intelectualmente dañino, afirmando en 1908 que el "ideal moral es la ley científica de la voluntad, no nada indeciso y utópico" (La conservación de la cultura, OC, I, 151). Ortega reconoce dos utopismos: uno bueno y otro malo. El falso utopismo consiste "en creer que lo que el hombre desea, proyecta y se propone es, sin más, posible". El buen utopista, por el contrario, "se compromete consigo mismo a ser primero un inexorable realista" (Véase Miseria y esplendor de la traducción, OC, V, 712-713).

26 Adán en el paraíso, OC, II, 60 y ss. En 1910 se encuentran los orígenes de la teoría perspectivista de Ortega. La doctrina del punto de vista que Ortega desarrolla y sistematiza en 1916 en "Verdad y perspectiva" - " $L a$ realidad, pues, se ofrece en perspectivas individuales. Lo que para uno está en último plano, se halla para otro en primer término (Verdad y perspectiva, OC, II, 163)-, es posible que Ortega la leyera en la obra de Husserl, pues dice este que "vemos las mismas cosas, sólo que cada uno las ve desde su punto de vista, en una orientación y en general en una manera de aparición que nunca puede ser a la vez la del otro" (E. Husserl. Ideas relativas a una fenomenología pura y una filosofía fenomenológica. Libro segundo: investigaciones fenomenológicas sobre la constitución, México, Universidad Nacional Autónoma de México, 1997, pp. 372 y ss).

27 Arte de este mundo y del otro, OC, I, 436.

28 En 1929 Ortega dirá que "todo el que en Europa vive seriamente la labor filosófica sabe -cualquiera que sea su personal restitución- que «logística» y «fenomenología» han sido posibilidades de primer orden, dos hallazgos esenciales de nuestro tiempo, cuyo desconocimiento condena una mente técnica a irremediable inferioridad" ([Sobre la fenomenología], OC, VIII, 185). Bien es verdad que en su obra madura su posición ante la fenomenología es ambivalente, pues en este mismo texto, dice Ortega lo siguiente: "No obstante, concedo que si es debido para un filósofo actual conocer la fenomenología no es absolutamente necesario" (Ibíd., p. 185).

29 Renán, OC, II, 36. 
su filosofía condicionan, junto a las ineludibles circunstancias, el enfoque con que Ortega se aproxima a los diferentes temas que componen su obra de ensayista. En Meditaciones del Quijote, concretamente en "Lector” dice Ortega:

Bajo el título Meditaciones anuncia este primer volumen unos ensayos de varia lección que va a publicar un profesor de Filosofía in partibus infidelium. Versan unos -como esta serie de Meditaciones del Quijote- sobre temas de alto rumbo; otros sobre temas más modestos; algunos sobre temas humildes-; todos, directa o indirectamente, acaban por referirse a las circunstancias españolas. Estos ensayos son para el autor -como la cátedra, el periódico o la política- modos diversos de ejercitar una misma actividad, de dar salida a un mismo afecto. No pretendo que esta actividad sea reconocida como la más importante en el mundo; me considero ante mí mismo justificado al advertir que es la única de que soy capaz. El afecto que a ella me mueve es el más vivo que encuentro en mi corazón. Resucitando el lindo nombre que usó Spinoza, yo le llamaría amor intellectualis. Se trata, pues, lector, de unos ensayos de amor intelectual ${ }^{30}$.

Más adelante en el tiempo, Ortega, que ya ha dejado atrás el intelectualismo/ racionalismo o conceptualismo de sus inicios, dirá, inmerso como está en una etapa más emotivista/vitalista, que el amor intellectualis "de que habla Spinoza no existe. El amor, si es amor, no es nunca intelectual. Por lo mismo, tampoco puede decirse que es ciego; su misión no es ver"31.

Una vez realizada esta introducción y justificación de la elección del tema objeto de estudio, en las siguientes páginas de este trabajo, estudiaremos la teoría del amor que ilumina Meditaciones del Quijote, a través de la cual Ortega contribuye al enriquecimiento de toda una tradición de la que, en mi opinión, aquél se siente heredero y/o sucesor. En Estudios sobre el amor (1941) ${ }^{32}$ dice Ortega lo siguiente:

Desde hace dos siglos se habla mucho de amores y poco del amor. Mientras todas las edades, desde el buen tiempo de Grecia, han tenido una gran teoría de los sentimientos, las dos centurias últimas han carecido de ella. El mundo antiguo se orientó primero en la de Platón; luego, en la doctrina estoica. La Edad Media aprendió la de Santo Tomás y de los árabes; el siglo XVII estudió con fervor la teoría de las pasiones de Descartes y Spinoza. Porque no ha habido gran filósofo del pretérito que no se creyese obligado a elaborar la suya. Nosotros no poseemos ningún ensayo, en grande estilo, de sistematizar los sentimientos. Sólo recientemente los trabajos de Pfänder y Scheler vuelven a movilizar el asunto. Y en tanto, nuestra alma se ha hecho cada vez más compleja y nuestra percepción más sutil ${ }^{33}$.

$30 \quad$ Meditaciones del Quijote, OC, I, 747.

$31 \quad$ Estudios sobre el amor (Apéndice), OC, V, 856.

32 Dice Ortega: "Mal podríamos entendernos si antes no averiguamos lo que es propia y puramente el amor. Además, fuera empequeñecer el tema reducir el estudio del amor al que sienten, unos por otros, hombres y mujeres. El tema es mucho más vasto, y Dante creía que el amor mueve el sol y las otras estrellas. Sin llegar a esta ampliación astronómica del erotismo, conviene que atendamos al fenómeno del amor en toda su generalidad" (Estudios sobre el amor, OC, V, 457). Los capítulos de «Estudios sobre el amor» fueron publicados primeramente como folletones en el diario El Sol, de Madrid, en los años 1926 y 1927, y después reunidos en un libro del que apareció en 1933 la traducción alemana, antes de la primera edición española, que no fue puesta a la venta hasta 1941 .

33 Estudios sobre el amor, OC, V, 457. 
El amor es, por tanto, para Ortega uno de los grandes problemas filosóficos del pensamiento occidental y como problema de esa naturaleza requiere un abordaje como el que describe el filósofo español en 1929 en ¿Qué es filosofía?:

Los grandes problemas filosóficos requieren una táctica similar a la que los hebreos emplearon para tomar a Jericó y sus rosas íntimas: sin ataque directo, circulando en torno lentamente, apretando la curva cada vez más y manteniendo vivo en el aire son de trompetas dramáticas. En el asedio ideológico la melodía dramática consiste en mantener despierta siempre la conciencia de los problemas, que son el drama idea $1^{34}$.

Semejante asedio intelectual es el que Ortega acometió para abordar el tema del amor como trataré de seguir mostrando a lo largo de las siguientes páginas de este trabajo.

En el siguiente apartado, mostraremos algunas de las fuentes clásicas que inspiraron a Ortega en su reflexión sobre el amor en su primera época. Me estoy refiriendo a la teoría del amor en Sócrates y Platón.

\section{Fuentes clásicas en la reflexión orteguiana sobre el amor a la altura de 1914. Más allá de Cervantes y El Quijote. La filosofía de Sócrates y Platón ${ }^{35}$}

Ortega siempre se ha inspirado en autores clásicos para enriquecer su pensamiento en multitud de temas o aspectos. En Meditaciones del Quijote, Ortega tiene como horizonte de inspiración El Quijote, la novela universal como asimismo lo es su autor, Miguel de Cervantes ${ }^{36}$.

Desde esta atalaya que representa la magistral obra literaria, Ortega se enfrenta al problema que intelectual y vitalmente más le atizó, a saber: el problema de España como nación: "Quiera o no, tengo que resolver el problema intelectual que me plantea mi circunstancia -esto es la cultura teorética-, tengo que reabsorber en teoría mi circunstancia, mi vida" 37 .

Con el objetivo de encontrar al problema español una solución o al menos lograr su comprensión, Ortega recurre a la figura de ese pobre semidiós alcabalero, como refiere Ortega a Cervantes, al estilo o manera cervantina de acercarse a las cosas para lograr, como digo, comprender mejor la realidad histórica de nuestra nación. No se puede negar que El Quijote y sobre todo el estilo de su autor, es un motivo

34 ¿Qué es filosofía?, OC, VIII, 236-237.

35 En la biblioteca personal de Ortega encontramos múltiples obras de Platón -al que Ortega cita en sus Obras completas: Platón: Platonis Euthyphro; Apologia Socratis; Crito; Phaedo / post Carolum Fridericum Hermannum ; recognovit Martinus Wohlrab.Ed. Stereotypa, Lipsiae : B. G. Teubneri, 1914; Platón: Oeuvres complètes; texte établi et traduit par Maurice Croiset. Paris: "Les Belles Lettres", 1920-<1985>. Platón: Platón el divino: diálogos platónicos / traducción directa por Emeterio Mazorriaga. Madrid: Librería y Casa Editorial Hernando, 1931.

36 Así lo ha puesto también de relieve el profesor y maestro orteguiano, Pedro Cerezo Galán en su trabajo "Cervantes y El Quijote en la aurora de la razón vital", Revista de Occidente, no 312, pp. 5-34. El individuo Don Quijote, dice Ortega, "es un individuo de la especie Cervantes” (Meditaciones del Quijote, OC, I, 761). Véanse también las "Notas de trabajo sobre Cervantes y El Quijote", ed. de José Ramón Carriazo e Isabel Ferreiro

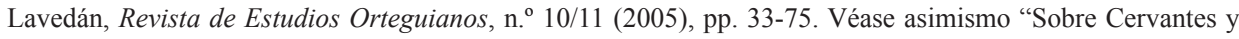
el Quijote desde El Escorial. (Notas de trabajo de José Ortega y Gasset), presentación de José Luis Molinuevo, Revista de Occidente, n 156, 1994, pp. 36-54.

37 [Vida como ejecución, (el ser ejecutivo)]. [Lecciones del curso 1929-1930], OC, VIII, 223. 
fundamental para entender el trasfondo de Meditaciones del Quijote, cuya filosofía, a mi juicio, es deudora de Cervantes y El Quijote. No en vano dice Ortega que: "Ah! Si supiéramos con evidencia en qué consiste el estilo de Cervantes, la manera cervantina de acercarse a las cosas, lo tendríamos todo logrado"38. Pero ya había dicho Ortega con anterioridad en Meditaciones lo siguiente: "Éste es para mí el verdadero quijotismo: el de Cervantes, no el de Don Quijote. Y no el de Cervantes en los baños de Argel, no en su vida, sino en su libro. Para eludir esta desviación biográfica y erudita, prefiero el título quijotismo a cervantismo"39.

Sin embargo, Ortega en Meditaciones no reduce su discurso a Cervantes y El Quijote, ya que "estas meditaciones, a que seguirán otras, renuncian -claro está-, a invadir los secretos últimos del Quijote. Son anchos círculos de atención que traza el pensamiento -sin prisas, sin inminencia-, fatalmente atraído por la obra inmortal"40.

Bien es verdad que la universal novela cervantina contiene, y Ortega así lo reconocía, los secretos de la vida, siendo la vida como enigma bajo la fórmula raciovitalista lo que encontramos en Meditaciones del Quijote que contiene toda una filosofía, aun cuando Ortega diga que sus ensayos no responden a esta disciplina. No se puede negar tampoco que su teoría del amor como afán de comprensión y que en un primer momento es, como ya indiqué anteriormente, más intelectualista-Ortega habla en varias partes de su obra primeriza de amor intellectualis- que fundada en el sentimiento o la pasión, encuentra justificación en el estilo cervantino que evita -censurando al mismo tiempo- los extremos (Don Quijote con su culto al ideal y Sancho sumido en lo trivial/material, son sendos ejemplos), y que busca comprender la realidad en toda su complejidad desde una posición humanista clasicista e integral que desde el amor a la comprensión trata de corregir los excesos de idealismo y su contrario, el materialismo. Pues como dice Ortega en Meditaciones: "Si la «idea» triunfa, la «materialidad» queda suplantada y vivimos alucinados. Si la materialidad se impone, y penetrando el vaho de la idea reabsorbe ésta, vivimos desilusionados" ${ }^{\prime 4}$.

Sin embargo, más allá de Cervantes y El Quijote, en Meditaciones son otros los autores en que Ortega se inspiró en relación a un tema como es el del amor que vehicula su reflexión, pues Ortega encuentra la justificación de estos ensayos de amor intelectual, como él mismo los denomina, en el hecho de que bajo la tierra espiritual de los mismos, va fluyendo, "riscosa a veces y áspera -con rumor ensordecido, blando, como si temiera ser oída demasiado claramente-, una doctrina de amor"42. Pero sobre todo nos interesa lo que dice después, a saber: que entre las varias actividades de amor "sólo hay una que pueda yo pretender contagiar a los demás: el afán de comprensión. Y habría henchido todas mis pretensiones si consiguiera tallar en aquella mínima porción del alma española que se encuentra a mi alcance algunas facetas nuevas de sensibilidad ideal (...). «Llámase en un diálogo platónico a este afán de comprensión (...), locura de amor. Pero aunque no fuera la forma originaria, la génesis y culminación de todo amor un ímpetu de comprender las cosas, creo que es su síntoma forzoso" ${ }^{\prime 43}$.

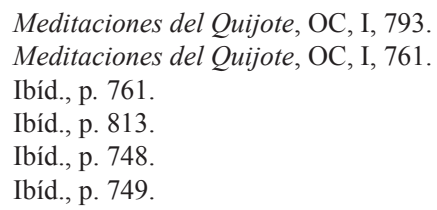


El diálogo platónico a que se refiere Ortega pero que no cita expresamente en Meditaciones del Quijote no es otro que Fedro. Ortega se refiere, sin embargo, al Fedro en el tomo II de sus Obras completas cuando dice que Platón, al descubrirnos en el Fedro la ciencia del amor "que es la ciencia de la ciencia, cuida de presentarnos a Sócrates y su amigo dialogando en una siesta canicular, al margen de Ilisos, bajo el frescor de un alto plátano sublime en tanto que sobres sus cabezas las cigarras helénicas vertían su rumor" ${ }^{44}$. Es en Fedro donde, en efecto, Sócrates, el partero equívoco y vagabundo, dialogando con Fedro sobre las cosas del amor o ta erotiká, dice que "afirmamos que el amor es una suerte de locura, ¿no es cierto? Fedro: Sí" Se trata de un forma de locura divina que como tal Sócrates la divide en cuatro partes, "relacionadas con cuatro dioses, y adjudicamos la inspiración profética a Apolo, a Dionisos la iniciática, a las Musas la poética, y una cuarta a Afrodita y Eros, la locura amorosa, que, dijimos, era la mejor" ${ }^{46}$. Locura de amor que es la mejor por cuanto fomenta la unión o la íntima conexión frente al odio que es inconexión, aniquilamiento que aboca al conflicto, la separación y/o desunión.

Ortega, recurriendo al Banquete de Platón -otro de los diálogos de Platón que Ortega leyó- dice que "va ligando el amor cosa a cosa y todo a nosotros, en firme estructura esencial. Amor es un divino arquitecto que bajó al mundo -según Platón (...) «a fin de que todo en el universo viva en conexión». La inconexión es el aniquilamiento. El odio que fabrica inconexión, que aísla y desliga, atomiza el orbe y pulveriza la individualidad" ${ }^{47}$. Esta misma idea relativa a la importancia de la conexión que promueve el amor frente a la hostilidad que distancia a los humanos sin remisión, la encontramos también en otro lugar del diálogo El Banquete de Platón ${ }^{48}$. En su diálogo El Banquete, Platón pone en boca del comensal Agatón lo siguiente:

44 Muerte y resurrección, OC, II, 284.

45 Platón. Fedro, introducción, traducción, notas y comentario de Armando Poratti, Madrid, Akal, 2010, p. 181.

46 Ibíd., p.183. Platón, de quien "gentes distraídas aseguran que fue un fugitivo del mundo sensible, no cesa de repetir que la educación hacia lo humano ha de iniciarse forzosamente en esta lenta disciplina de los sentidos, o como él dice: tà eroticá” (Los versos de Antonio Machado, OC, II, 147). En otro lugar dice Ortega: “¿Cómo se ha podido presentar a Platón como un fugitivo del mundo? ¿Quién como él ha afirmado que toda educación tiene que empezar por tà eroticá, por la educación de los sentidos? ¿No toma de la visión la metáfora fundamental de su idea? Cuando quiere aclarar qué es su idealismo, encuentra sólo el eros -el amor. El amor no ama al amado. El amor es la ideación del amado" (La "idea” de Platón, OC, VII, 231).

47 Meditaciones del Quijote, OC, I, 749. Para Platón, dice Ortega, "es el amor una manía «divina»" (Estudios sobre el amor, OC, V, 485). En otro lugar Ortega refiere la idea de Platón "sobre el origen erótico del conocimiento" (¿Qué es filosofía?, OC, VIII, 366). Son múltiples las citas al filósofo ateniense a propósito del amor y otras temáticas que desafortunadamente no pueden ser objeto de este trabajo de investigación.

48 Buena prueba de que Ortega leyó El Banquete no es solamente el hecho de que las Obras de Platón aparezcan en su biblioteca personal, sino también su trabajo «[Apuntes para un comentario al Banquete de Platón]», OC, IX, 729-758, así como las referencias a aquel diálogo del divino filósofo ateniense, como Ortega lo refiere, en sus Obras completas: "Lo que hoy llamamos sabiduría griega fue tal vez inútil para Grecia, y, sin embargo, de entonces acá nos hemos ido nutriendo, generación tras generación, en el Banquete de Platón, y en la Politeia o Constitución civil encontramos asimismo sembrados por este divino heleno motivos, temas políticos que hasta hoy no habían cobrado interés práctico, y hoy lo tienen tal, que es casi un interés estomacal (Sobre el Santo, OC, II, 23). Es indudable también que Ortega leyó La República, pues en su trabajo Asamblea para el progreso de las ciencias de 1908 cita Ortega La República (Véase Asamblea para el progreso de las ciencias, OC, I, 186). Así como en 1910 dice el filósofo español lo siguiente: "Así, hace veinticuatro siglos, Platón en la República: "¿A qué hablamos de "la" ciudad? ¿No es, por ventura, cada ciudad muchas ciudades? ¿No es, por lo menos, cada ciudad dos ciudades que viven juntas en perpetua lucha, la ciudad de los pobres y la ciudad de los ricos?»" (Imperialismo y democracia, OC, I, 320). 
Esta es mi opinión Fedro: el Amor, por ser ante todo sumamente bello y excelente en sí, es causa después para los demás de otras cosas semejantes. Y se me ocurre también decir en verso que es él quien crea: En los hombres la paz, en el piélago calma sin brisa, el reposo de los vientos y el sueño en las cuitas. Es él quien nos vacía de hostilidad y nos llena de familiaridad, quien ha instituido todas las reuniones como ésta para que las celebremos en mutua compañía y el que en las fiestas, en las danzas y en los sacrificios se hace nuestro guía; nos procura mansedumbre, nos despoja de rudeza; amigo de dar benevolencia, jamás da malevolencia, es benigno en su bondad ${ }^{49}$.

No es casualidad que Ortega recurra a Platón para ilustrar el tema del amor si tenemos en cuenta los comentarios tan favorables que Ortega realiza sobre figura tan decisiva en el pensamiento filosófico occidental. De entre las ruinas helénicas Ortega rescata a Platón a propósito del amor, al menos en la significación que el filósofo griego confiere a éste como elemento que contribuye a forjar un universo en conexión. Ortega admira la cantera de ideas platónica: "Ocurre que luego de veinticuatro siglos continuamos sacando piedra nueva de la cantera platónica: Platón vive aun realmente, aún no es un pasado: Platón, por consiguiente, es un genio. La genialidad es, pues, un valor experimental" 50 . Dice también Ortega que "quien no haya meditado a Platón, tiene menos peso específico, dentro de la zoología, que quien lo haya glosado. No asimilarse la cultura griega -que Ortega ejemplifica en la obra de Platón- equivale a ser menos hombre, y significa una mayor aproximación al canguro" 51 .

Con sus referencias a los diálogos de Platón a propósito del amor, Ortega está recuperando una tradición con más de veinticinco siglos de historia en el pensamiento filosófico donde destacan a propósito del amor, los mentados diálogos de Platón, -El Banquete y Fedro, a los que también se refiere por su conexión con la obra del filósofo español, Inman Fox en su edición de Meditaciones sobre la literatura y el arte (La manera española de ver las cosas) ${ }^{52}$-, si bien antes de él, encontramos reflexiones sobre el amor en el presocrático Empédocles de Agrigento quien hizo de su filosofía un debate sobre la eterna lucha entre el amor (philía, representado por Afrodita) y el odio (neíkos) ${ }^{53}$.

Ortega conocía esta tradición del pensamiento occidental sobre el amor que él interpreta desde la figura de Platón, divino filósofo como divino es el amor, que auxilió a Ortega en su reflexión filosófica sobre tan importante cuestión en un tiempo, y de ahí el énfasis de Ortega en Meditaciones del Quijote y en algunos otros textos de su producción, en que, como él mismo afirma en Leyendo El Adolfo, Libro de Amor (1916), "la religión y el amor tienen la desgracia de que no se suele pensar en ellos sino religiosamente y amorosamente. De esta manera hemos hecho de esas dos cosas radiantes y benéficas dos cosas turbias, exageradas, fantasmagóricas, cuando

\footnotetext{
Platón. El Banquete, Madrid, Tecnos, 2006, p. 44.

¿Una exposición Zuloaga?, OC, I, 343.

La teología de Renán, OC, I, 334.

Véase I. Fox. Meditaciones sobre la literatura y el arte (La manera española de ver las cosas, Madrid, Editorial Castalia, 1988, pp. 54-55.

53 Véase sobre la filosofía presocrática en la historia del pensamiento en Occidente, la obra ya clásica de C.S. Kirk, J.E. Raven, y. M. Schofield. Los filósofos presocráticos: historia crítica con selección de textos /; versión española de Jesús García Fernández, Madrid, Gredos, 1987.
} 
no atroces instrumentos de martirio" ${ }^{54}$. En este mismo trabajo de 1916, dice más adelante Ortega que abriga "la creencia de que nuestra época va a ocuparse del amor un poco más seriamente que era uso. Va a tener el valor de mirar cara a cara el problema del amor (...). Hablará, pues, a menudo de estas cosas, las únicas en que Sócrates -patrón de los filósofos, le llama Ortega- se declaraba especialista: ta erotiká: las cosas del amor" ${ }^{55}$.

Sin embargo, más adelante, en 1917, preso nuevamente de la desesperanza, dice que "nuestra edad, estúpidamente sensual, es una de las que menos ha pensado sobre el amor, de las menos cultas en amor. Hasta el extremo de que yo tengo que hablar del «amor» entre comillas para advertir que hablo del amor entre personas y no entre cuerpos" 56 .

El pensamiento de Ortega no languidece en este desfavorable contexto hacia las cosas del amor o ta erotika, realizando una contribución a esta temática desde la autoridad que le presta el conocimiento de esta tradición en el pensamiento filosófico occidental, como también desde su particular filosofía en la cual el amor, como estamos viendo en este trabajo de investigación, ocupa un lugar de mención.

Desde el pensamiento clásico griego, Ortega elabora una teoría del amor que aquél entiende como afán filosófico de comprensión del sentido de las cosas de nuestro más inmediato derredor. Comprensión que según el filósofo español también nos muestra la conexión o vínculo entre todas ellas, razón por la cual Ortega ya desde 1909 en su trabajo Renán afirma, en esta ocasión respondiendo a Spinoza, que "cada cosa -afirma Spinoza- aspira a perseverar en su ser. No, no; la fórmula no es suficiente; cada cosa viva aspira a ser todas las demás" $" 57$.

En el próximo apartado de este trabajo, nos ocuparemos del fenómeno del amor y el odio en la teoría ético-filosófica de Ortega mostrando asimismo las interferencias

54 Leyendo El Adolfo, Libro de Amor, OC, II, 169.

55 Leyendo El Adolfo, Libro de Amor, OC, II, 169-170. Dice Ortega: “¿Quién puede calcular las revelaciones que el estudio y la política del amor nos reservan? Baste con advertir que desde todos los tiempos ha sido lo erótico sometido a un régimen de ocultación. ¿Por qué? La cuestión parece demasiado difícil para ser ahora ni siquiera rozada. El hecho es que el hombre se ha acostumbrado a encerrar su vida erótica en una cárcel secreta del alma (...): ¡Cuántas cosas, sobre todo cuántas acciones de los hombres que nos parecen incomprensibles tienen su origen y su explicación en esas oficinas ocultas del amor!" (Leyendo El Adolfo, Libro de Amor, OC, II, 170). Antonio Rodríguez Huescar tiene claro que la paideia socrática y la politeia platónica, son "magisterios ambos de relevante importancia en la formación orteguiana" (A. Rodríguez Huéscar. "Reflexiones sobre Ortega y la política". Revista de Occidente, Madrid, $\mathrm{n}^{\circ} 72$, 1987, pp. 8 y s). Las referencias a Sócrates también son múltiples en sus Obras completas. A modo de ejemplo y en relación al tema del amor: "La juventud necesita la pedagogía del amor. Mirad: el viejo y socarrón Sócrates solía en las tardes de estío llevar algún discípulo por las márgenes amenas del Cefiso. Y allí en la soledad y como al oído, cuenta Platón que le revelaba un secreto: Yo digo, murmuraba Sócrates, que sólo sé que no sé nada-pero esto no es verdad. ¡Hay un asunto, sólo un asunto en el que confieso ser especialista!, ta\ [e)rotika/], las cosas del amor. Y en tanto que esto decía, agrega Platón, sobre sus cabezas [, puestas en los plátanos, las áticas cigarras caniculares rascaban en su rabel] ([Elogio de las virtudes de la mocedad], OC, VII, 841).

56 Para la cultura del amor, OC, II, 280. En este trabajo dice Ortega refiriéndose al pensamiento filosófico sobre el amor: "Pero ¿hay quien crea que tal «amor» existe? Únicamente los que creen en el amor platónico, en el cual yo no creo, ni Platón tampoco... Y, sin embargo, ya Plotino distingue del divino Eros, de la Urania Afrodita lo que él llama Afrodita Pandemos, esto es, el amor de todo el mundo, el vulgar amor. Pues bien: a ése me refiero. Y quisiera mostrar que, lejos de contener fuerza mística alguna, es un trivial mecanismo psicológico que a toda hora está funcionando en nosotros. Mas por lo mismo que es trivial, yo veo en él una magnífica potencia pedagógica que debíamos más ampliamente cultivar" (Ibíd., p. 280).

57 Renán. Teoría de lo verosímil, OC, II, 41. En Adán en el paraíso (1910) dice Ortega que "un individuo, sea cosa o persona, es el resultado del resto total del mundo: es la totalidad de las relaciones. En el nacimiento de una brizna de hierba colabora todo el universo" (Adán en el paraíso, OC, II, 68). 
político-sociales del tema del amor en la España de la Restauración que Ortega identifica con la vieja política símbolo de una España oficial que anula las corrientes de vitalidad nacional (Universidad, escuela rural, Parlamento, periódico, etc.)., aquellas que según el filósofo español hay que potenciar en el contexto de una España vital, vertebrada y en pie -como anuncia ya desde 1910-, siendo el amor hacia las mismas un elemento fundamental de regeneración social. Lo que se impone, sin embargo, al amparo de aquel régimen, es el odio y el resentimiento en la moral que impactan en el ámbito de la convivencia social.

\section{Amor y odio en la teoría ético filosófica de Meditaciones de Quijote. Interferencias político sociales del fenómeno del amor en la España de la Restauración}

Como ya se adelantó al comienzo de este trabajo de investigación, Ortega en Meditaciones del Quijote vierte su teoría del amor en lo que se conoce, en relación a su pensamiento, como el problema español.

¿Cuál es el problema de España que genera en él tanta preocupación y cuya solución somete Ortega a experimentación (recordemos que las Meditaciones del Quijote son experimentos de nueva España)? El problema español es un problema de difícil solución ya que anida en la forma de ser del tipo medio español, del que dice Ortega que "es un centro de fiereza que irradia en torno odio y desprecio" que conducen "al aniquilamiento y la inconexión”. A los españoles, afirma Ortega señalando la situación social que acontece en la España de la Restauración, "un terrible resorte de acero los mantiene separados, prestos, si cediera, a lanzarse unos sobre otros. Cada conversación está a punto de convertirse en un combate cuerpo a cuerpo; cada palabra, en un bote de lanza; cada gesto, en un navajazo"58. Y en 1915 en Notas de andar y ver, dice Ortega que en nuestro país no es uso vivir abierto,

a todos los vientos. Casi todas las gentes parecen atormentadas por la sospecha de que alguien va a venir y les va a arrebatar su ser - este menudo pensamiento, esta pequeña fortuna, este puestecillo en la jerarquía política o académica. Y toda su vida se convierte en una táctica defensiva contra los demás, compuesta de odio, de acritud, de maledicencia, de intriga, de fraude ${ }^{59}$.

Ortega constata, pues, que el amor ha cedido al resentimiento, la enemistad o el odio en el alma del individuo medio español, lo que conduce asimismo al predomino de una situación moral decadente que aboca a la desesperación y la invertebración por falta de apego en el ámbito social convivencial. No es que carezcamos de moral, sino que lo que impera es una moral sustentada en la perversidad. Ortega deja claro en Meditaciones del Quijote, en lo que sería la dimensión ético-filosófica pero también axiológica de su primera gran obra, que no le es indiferente el ideal moral:

Yo no desdeño la moralidad en beneficio de un frívolo jugar con las ideas. Las doctrinas inmoralistas que hasta ahora han llegado a mi conocimiento carecen de sentido común

Una primera vista sobre Baroja (Apéndice), OC, II, 254.

Notas de andar y ver, OC, II, 385. 
(...). Pero, en reverencia del ideal moral, es preciso que combatamos sus mayores enemigos, que son las moralidades perversas. Y en mi entender -y no sólo en el mío-, lo son todas las morales utilitarias (...). Sólo nos parece moral un ánimo que antes de cada nueva acción trata de renovar el contacto inmediato con el valor ético en persona (...): Por tanto, será inmoral toda moral que no impere entre sus deberes el deber primario de hallarnos dispuestos constantemente a la reforma, corrección y aumento del ideal ético. Toda ética que ordene la reclusión perpetua de nuestro albedrío dentro de un sistema cerrado de valoraciones es ipso facto perversa. Como en las constituciones civiles que se llaman abiertas, ha de existir en ella un principio que mueva a la ampliación y enriquecimiento de la experiencia moral (...). Con elevada conciencia de esto, Flaubert escribía una vez: «El ideal sólo es fecundo -entiéndase moralmente fecundo -cuando se hace entrar todo en él. Es un trabajo de amor y no de exclusión». No se opone, pues, en mi alma la comprensión a la moral. Se opone a la moral perversa la moral integral para quien es la comprensión un claro y primario deber. Merced a él crece indefinidamente nuestro radio de cordialidad, $y$, en consecuencia, nuestras probabilidades de ser justos ${ }^{60}$.

Lo que está proponiendo Ortega es una moral integral o fecunda que se funde en el amor destacando el valor ético en persona. Se trata de una ética axiológica del amor abierta a la comprensión /conexión que aborrece la exclusión, como el propio Ortega nos transmitió. De ahí que en Meditaciones del Quijote, el filósofo español denuncie, concretamente en "Lector", lo siguiente:

la morada íntima de los españoles fue tomada tiempo hace por el odio, que permanece allí artillado, moviendo guerra al mundo. Ahora bien; el odio es un afecto que conduce a la aniquilación de los valores. Cuando odiamos algo, ponemos entre ello y nuestra intimidad un fiero resorte de acero que impide la fusión, siquiera transitoria, de la cosa con nuestro espíritu. Sólo existe para nosotros aquel punto de ella donde nuestro resorte de odio se fija; todo lo demás, o nos es desconocido, o lo vamos olvidando, haciéndolo ajeno a nosotros. Cada instante va siendo el objeto menos, va consumiéndose, perdiendo valor. De esta suerte se ha convertido para el español el universo en una cosa rígida, seca, sórdida y desierta (...). Por el contrario, el amor nos liga a las cosas, aun cuando sea pasajeramente (...). Hay, por consiguiente, en el amor una ampliación de la individualidad que absorbe otras cosas dentro de ésta, que las funde con nosotros. Tal ligamen y compenetración nos hace internarnos profundamente en las propiedades de lo amado. Lo vemos entero, se nos revela en todo su valor. Entonces advertimos que lo amado es, a su vez, parte de otra cosa, que necesita de ella, que está ligado a ella. Imprescindible para lo amado, se hace también imprescindible para nosotros ${ }^{61}$.

Sin embargo, Ortega advierte que "los españoles ofrecemos a la vida un corazón blindado de rencor, y las cosas, rebotando en él, son despedidas cruelmente. Hay en derredor nuestro, desde hace siglos, un incesante y progresivo derrumbamiento de los valores" 62 .

La España oficial, que es a la que se refiere Ortega, padece la perversión moral de todo ser íntimamente fracasado, "y que algunos psicólogos de nuestro tiempo llaman

\footnotetext{
Meditaciones del Quijote, OC, I, 750-751.

Ibíd., p. 748.

Meditaciones del Quijote, OC, I, 749.
} 
resentiment. Consiste esta perversión en odiar todo valor superior (...) y favorecer contra él cualquier valor negativo e inferior" ${ }^{63}$. Se odia todo lo superior, excelente o egregio. Se favorece el imperio de los viles o los necios, que "ha roto aquella cohesión radical, y hoy cada núcleo español, por no decir cada individuo, ha perdido por completo la sensibilidad para el resto del cuerpo social" 64 .

El análisis orteguiano del resentimiento de las masas-que las hay en toda clase o grupo, dirá Ortega desde aproximadamente 1920- guarda relación con los análisis de F. Nietzsche y Max Scheler. Ortega, como ya referimos, dice que con aguda mirada ya había Nietzsche descubierto en ciertas actitudes morales "formas y productos del rencor" 65 , así como más adelante, en otro trabajo dice Ortega que "Nietzsche descubrió genialmente el mecanismo del alma rencorosa, lo que él llamó resentimiento" 66 .

Recordemos que Nietzsche, en el marco de sus críticas a la moral decadente judeo-cristiana, comenta que se ha considerado "hombres grandes a los hombres más nocivos (...). La humanidad ha estado hasta ahora en las peores manos (...), ha sido gobernada por los fracasados, por los astutos vengativos, los llamados santos, esos calumniadores del mundo y violadores del hombre" ${ }^{67}$. En su Genealogía de la moral, Nietzsche expone por vez primera el mecanismo psicológico que subyace a la moral de ressentiment judeo-cristiana. Ésta consiste en negar los valores de la moral aristocrática. Pero va a ser en su obra El Anticristo donde Nietzsche afirme lo siguiente:

El cristianismo ha hecho una guerra a muerte a todo sentimiento de respeto y de distancia entre los hombres, es decir, el presupuesto de toda elevación, de todo crecimiento, de toda cultura, con el resentimiento de las masas ha forjado su arma capital contra nosotros, contra los seres aristocráticos, joviales, generosos que hay en la tierra, contra nuestra felicidad en la tierra ${ }^{68}$.

Cada día adquiere mayor predominio, afirma Ortega en Mirabeau o el político (1927), "la moral canija de las almas mediocres, que es excelente cuando está compensada por los fieros y rudos aletazos de las almas mayores, pero que es mortal cuando pretende dirigir una raza, y apostada en todos los lugares estratégicos, se dedica a aplastar todo germen de superioridad" 69 .

Por su parte, Max Scheler, en su análisis sobre la génesis psicológica del resentimiento parte de que todos "realizamos continuamente valoraciones entre

63 Una carta, O.C, III, 354.

${ }_{64}$ Todo es posible en España, O.C, III, 358. Más adelante en Musicalia Ortega vuelve a recordar este asunto del rencor de la mano de Nietzsche y en el marco de su pensamiento elitista y de su crítica social a la actitud de la muchedumbre que da en odiar todo lo egregio, sobrevalorando lo vulgar: "Cuanto vale algo sobre la tierra ha sido hecho por unos pocos hombres selectos, a pesar del gran público, en brava lucha contra la estulticia y el rencor de las muchedumbres. Con no poca razón medía Nietzsche el valor de cada individuo por la cantidad de soledad que pudiese soportar, esto es, por la distancia de la muchedumbre a que su espíritu estuviera colocado" (Musicalia, OC, II, 365).

65 Meditaciones del Quijote, OC, I, 750.

66 Introducción a un Don Juan, OC, VI, 197.

67 F. Nietzsche. Ecce homo, traducción de Andrés Sánchez Pacual, Madrid, Alianza, 1985, pp. 53 Y s.

68 F. Nietzsche. El Anticristo, traducción, introducción y notas de Andrés Sánchez Pascual, Madrid, Alianza, 1980, pp. $50 \mathrm{~s}$.

69 Mirabeau o el político, O.C, IV, 202. 
nuestro propio valor, o el valor de algunas de nuestras cualidades, y los valores ajenos; y las realizamos todos, el egregio y el vulgar, el bueno y el malo". Sin embargo, hay, afirma Scheler, una gran diferencia entre el primero y el segundo:

Esta diferencia radica en que mientras el distinguido vive los valores antes de la comparación; el vulgar, sólo en y mediante la comparación. La estructura: relación entre el valor propio y el ajeno, se convierte para el vulgar en la condición selectiva de su percepción de los valores. No puede aprehender en otros ningún valor sin tomarlo a la vez como superior o inferior, como mayor o menor que su propio valor; sin medir a los demás consigo y a sí mismo con los demás ${ }^{70}$.

El resentido es el tipo débil que, impotente para realizar los auténticos valores superiores, destila odio, envidia y deseo de venganza hacia aquellos que los encarnan. El resentimiento es una perversión del sentimiento estimativo que convierte en negativos los valores positivos para un sentimiento estimativo normal. El resentimiento es, por tanto, el resultado de la confluencia entre la impotencia, por un lado, y los impulsos reactivos de venganza, odio y envidia, por otro. El resentimiento no es, para Scheler, la semilla de la ética cristiana, sino de la moral burguesa ${ }^{71}$.

Y esta es la situación, en lo que al resentimiento se refiere, que Ortega percibe en el contexto de la llamada España oficial, la cual fomenta el odio y no el amor, así como se dedica a la aniquilación de los mejores o de los individuos más sobresalientes: "Cuando alguien hace algo mejor (...) la España oficial se resuelve airada contra él y se dispone aniquilarlo (...). La España oficial se dedica indefectible y metódicamente a triturar cuanto en el área nacional aparece dotado de cualidades valiosas"72. Confundir al diestro con el inepto o al noble con el ruin ha sido una constante, sin embargo, en la historia de España:

En su Historia de la decadencia del mundo antiguo titula Otto Seeck, el capítulo más grave: Aniquilamiento de los mejores. La historia nacional del tiempo que voy viviendo puede titularse, dice Ortega, con estas mismas palabras. Desde que tengo uso de razón asisto al indefectible fracaso de nuestros hombres mejores, rendidos por tener que emplear sus facultades arcangélicas contra boxeadores cotidianos. Los espíritus selectos que en la península se esfuerzan por aumentar la cultura española deberían hacer la travesía del Atlántico a fin de reconfortarse. Estén seguros de que allende el mar no serán confundidos y cobrarán fe en el sentido de su esfuerzo ${ }^{73}$.

Pero va a ser la vieja política quien reciba las críticas más arduas por parte del filósofo raciovitalista, pues, como ya dijimos y nos permitimos reproducir aquí otra vez, Ortega se lamenta de que perdiose en la Restauración la sensibilidad "para todo lo verdaderamente fuerte, excelso, plenario y profundo (...). Fue, como Nietzsche diría, una etapa de perversión en los instintos valoradores"74. Es, en efecto, la total

70 Véase M. Scheler. El resentimiento en la moral, traducción de José Gaos, edición de José María Vegas, Madrid, Caparrós Editores, 1998, pp. 21 y ss.

71 Véase ibíd., pp. 21 y ss.

72 Una carta, O.C, III, 354.

73 Palabras a los suscriptores, O.C, II, 266 y ss.

74 Meditaciones del Quijote, O.C, I, 772. Una clase social odia a la otra, un grupo al otro y, en vez de secar las fuentes de esa odiosidad difusa, "los gobernantes se dedican a fabricar más rencor" (Fabricantes de rencor, O.C, 
inversión de los valores: "lo superior, precisamente por serlo, padece una capitis diminutio y en su lugar triunfa lo inferior"75. Del individuo inepto, torpe y vitalmente fracasado, aquel que contribuye a esa inversión de la tabla estimativa de valores superiores que supedita a los inferiores o de menor calibre, afirma Ortega lo siguiente:

Va por el mundo con su corazón rezumando desestima de sí mismo. Como no logra acallar este menosprecio de sí, que sopla en bocanadas de su propio interior y no le deja vivir, se produce en él una reacción salvadora, que consiste en cegarse para todo lo valioso que hay en torno. Ya que no puede estimarse a sí mismo, tenderá a buscar razones para desprestigiar toda excelencia; no verá sino los defectos, los errores, las insuficiencias de los hombres mejores, cuya presencia equivale para él a una constante humillación. De este modo obtendrá una apariencia de equilibrio entre los demás y él. Emboscado en su resentimiento, espiará a todo héroe con fiero ojo de cazador furtivo, complaciéndose en subrayar sus abandonos y sus descuidos ${ }^{76}$.

La crítica a la perversión estimativa (ámbito los valores) no la abandonará Ortega. En España Invertebrada (1922), aquél vuelve a la carga sobre la misma idea en lo que sería su oposición al particularismo/separatismo reinantes. Fenómenos que responden a un estado de espíritu en que se declina convivir con los demás, renegando de todo proyecto sugestivo de vida en común o de convivencia social: "El particularismo es aquel estado de espíritu en que creemos no tener por qué contar con los demás (....), comenzamos a sentirnos como todos independientes" 77 . El particularismo como perversión moral enferma a España, siendo así que Ortega pretende doblegarlo difundiendo una teoría/ética del amor que promueva la unión evitando la desconexión.

En el próximo apartado de este trabajo, atendemos a algunas otras fuentes en la teoría ético-filosófico-antropológica orteguiana del amor, acercándonos a dos autores, como son Spinoza y Max Scheler, a quienes ya hemos citado y que Ortega leyó.

\section{Algunas otras fuentes en la teoría orteguiana del amor. La ética de las pasiones/ afectos de Spinoza y la fenomenología del amor de Scheler como referentes de excepción}

En Meditaciones del Quijote, Ortega propone, de forma más o menos explícita, una serie de soluciones al que denomina -siguiendo toda una tradición-como problema español, pues solamente solucionando/solventando este problema logrará mitigar su desesperación en forma de mar de angustias, alcanzando tierra firme y tratando, por

III, 80).

75 Democracia morbosa, O.C, II, 274.

76 Introducción a un Don Juan, OC, VI, 197. En El Quijote en la escuela (1920), dice Ortega que existen dos pulsaciones vitales o formas del pulso vital, una ascendente y otra descendente. Si predomina la primera se genera un clima vital donde "no se dan, por lo menos con carácter normal, las envidias, los pequeños rencores y resentimientos". Pero si predominan los individuos con un pulso vital descendente, nos encontramos con un clima o atmosfera vital "en que la envidia fructifica y el resentimiento sustituye a la actitud amorosa, la suspicacia a la generosidad" ((El Quijote en la escuela, OC, II, 416).

77 España Invertebrada, OC, III, 465. 
tanto, de evitar el completo naufragio (El hombre es naufrago en un mar de dudas, dirá Ortega en su obra madura) que le sumiría en la más absoluta desolación.

Ortega trata de materializar sus esperanzas que se concretan en la salvación de la circunstancia española. Solo así logrará salvarse a sí mismo, pues aquél entiende que la circunstancia es la otra mitad de su persona. El afecto que a esta misión de salvación de las circunstancias españolas le mueve es, dice Ortega, "el más vivo que encuentro en mi corazón" 78 , siendo en este punto donde menciona expresamente y de forma contundente, por la apropiación que hará de su célebre expresión, a Spinoza ${ }^{79}$. Y así dice lo siguiente -las dos primeras líneas ya las citamos anteriormente-:

Resucitando el lindo nombre que usó Spinoza, yo le llamaría amor intellectualis. Se trata, pues, lector, de unos ensayos de amor intelectual. Carecen por completo de valor informativo; no son tampoco epítomes -son más bien lo que un humanista del siglo XVII hubiera denominado «salvaciones». Se busca en ellos lo siguiente: dado un hecho -un hombre, un libro, un cuadro, un paisaje, un error, un dolor-, llevarlo por el camino más corto a la plenitud de su significado. Colocar las materias de todo orden, que la vida, en su resaca perenne, arroja a nuestros pies como restos inhábiles de un naufragio, en postura tal que dé en ellos el sol innumerables reverberaciones. Hay dentro de toda cosa la indicación de una posible plenitud. Un alma abierta y noble sentirá la ambición de perfeccionarla, de auxiliarla, para que logre esa su plenitud. Esto es amor -el amor a la perfección de lo amado ${ }^{80}$.

Amor que Ortega entiende como afán de comprensión en un mundo o circunstancia, léase la España canovista de la Restauración, donde lo que impera, como señalamos en un apartado anterior, es justamente lo contrario, a saber: el odio y la incomprensión que abocan a la destrucción. Podemos encontrar cierto paralelismo entre la reflexión de Ortega y aquello que dice Spinoza en la Parte Tercera de su Ética. Del origen y naturaleza de los afectos. Quién sabe si Ortega no se inspiró en el filósofo judío para definir esta cuestión, probablemente así sea, a tenor de lo que dice Spinoza y por encontrarse éste, como sabemos, entre las lecturas de Ortega. Dice Spinoza: "Vemos, además, que el que ama se esfuerza necesariamente por tener presente y conservar la cosa que ama, y, al contrario, el que odia se esfuerza por apartar y destruir la cosa que odia" $"$. Y más adelante dice también aquél lo siguiente: "El odio nunca puede

78 Meditaciones del Quijote, OC, I, 747.

79 Entre las lecturas de Ortega, entre los aproximadamente 20000 volúmenes que conforman su biblioteca personal, se encuentran algunas de las obras de Spinoza, como podemos comprobar si visitamos aquélla en la Fundación José Ortega y Gasset /Gregorio Marañón de Madrid, en la cual aparecen por ejemplo, el Tratado Teológico Político (Leipzig: Feliz Mainer, 1922) y la Ética demostrada según el orden geométrico y dividida en cinco partes, publicada en París: Garnier Fréres, (1909), o el Tomo II de las Obras de Spinoza (París, Charpentier, 1842), o también el Epistolario, publicado en Buenos Aires, Sociedad Hebraica Argentina (1950).

80 Meditaciones del Quijote, OC, I, 747-748.

81 B. de Spinoza. Ética demostrada según el orden geométrico, edición preparada por Vidal Peña, Madrid, Editorial Nacional, 1984, p. 198. Para Spinoza, "el amor no es sino la alegría, acompañada por la idea de una causa exterior, y el odio no es sino la tristeza, acompañada por la idea de una causa exterior". La alegría es "una pasión por la que el alma pasa a una mayor perfección". Por tristeza, en cambio, entiende Spinoza, "una pasión por la cual el alma pasa a una menor perfección. Además, llamo al afecto de la alegría, referido a la vez al alma y al cuerpo, placer o regocijo, y al de la tristeza, dolor o melancolía” (Ibíd., p. 195). Más adelante dice Spinoza que “dichas tristeza y alegría serán, pues, formas del odio y el amor” (Ibíd., p. 212). En la página 245 de esta obra dice aquél que "la alegría es el paso del hombre de una menor a una mayor perfección" y la "tristeza es el paso del hombre de una mayor a una menor perfección” (Ibíd., p. 245). Spinoza afirma que los principales afectos y 
ser bueno. Nos esforzamos en destruir al hombre que odiamos (por la Proposición 39 de la Parte III), esto es (por la Proposición 37 de esta Parte) nos esforzamos en algo que es malo (...). Todos los afectos de odio son malos (por el Corolario 1 de la Proposición anterior); y así, quien vive bajo la guía de la razón se esforzará cuanto puede por no padecerlos (por la Proposición 19 de esta Parte), y, consiguientemente (por la Proposición 37 de esta Parte), se esforzará en que tampoco otro los padezca. Ahora bien, el odio se incrementa con un odio recíproco y, en cambio, puede ser destruido por el amor (por la Proposición 43 de la Parte III), de suerte que el odio se transforme en amor" 82 .

Ortega compartiría esta reflexión del filósofo judío sobre la necesidad de que el amor subyugue al odio en nuestro corazón, así como imbuido por la idea del amor, el pensador español, remitiendo a la obra de Platón como vimos también en un apartado anterior, se autodefine como un hombre agitado por el vivo afán de comprensión. Aun cuando las referencias a Platón son constantes en la obra de Ortega, es sin embargo, la referencia a Spinoza en las Meditaciones del Quijote la que introduce la teoría orteguiana de la filosofía como ciencia general del amor como afán de comprensión desde el intelecto, o como también dirá más adelante Ortega, desde el concepto. En Renán (1909), encontramos, no obstante, la primera referencia importante a Spinoza y su teoría del amor intelectual:

Es amor a la verdad una curiosidad severa que hace del hombre entero pupila hambrienta de ver cosas, que saca al individuo de sus propios goznes y prejuicios y le pone a arder en un entusiasmo visual (...). Este amor a la verdad, que se contenta con ver, es una acción pura, intelectual, algo así como lo que llama Spinoza amor intellectualis Dei (...). Decir la verdad es obedecer a un ímpetu muy distinto del que se contenta con la muda contemplación de lo verdadero; es aquél un ímpetu moral que considera la verdad, más bien que como verdad, como un bien humano que es debido imponer. Aquí el individuo se siente nominativamente solicitado. Es el amor lírico a la verdad, a la verdad en mín ${ }^{83}$.

El amor intelectual como amor a la verdad (el hombre es un ser verdadovoro), a la verdad en mí, confiere claridad, ya que el hombre, dice Ortega, tiene una misión de claridad sobre la tierra ${ }^{84}$. Esta misión no le ha sido revelada por un Dios ni le es

fluctuaciones del ánimo "surgen de la composición de los tres afectos primitivos, a saber: el deseo, la alegría y la tristeza" (Ibíd., 242).

82 B. de Spinoza. Ética demostrada según el orden geométrico, edición preparada por Vidal Peña, Madrid, Editorial Nacional, 1984, pp. 311 y ss.

83 Renán, OC, II, 37. José María Rodríguez Paniagua, afirma que "lo primero que hemos de advertir en este caso es que falta la palabra "Dei" que aparece en Spinoza entre las dos palabras anteriores ("amor" e "intellectualis"). Obviamente eso determina el sentido de la expresión completa, y también el que tienen cada una de sus palabras. En Spinoza el amor va referido a Dios, porque Él es la clave, la base y, por consiguiente, la causa de nuestro conocimiento, en especial de nuestro conocimiento supremo, el conocimiento intuitivo de las cosas a partir de los atributos divinos. Este (que incluye el conocimiento de Dios) es el supremo bien del alma humana y, por consiguiente, su consecución va acompañada de la mayor alegría, ya que ésta (la alegría) es el paso de una menor a una mayor perfección. Pero a su vez da lugar al amor, porque éste no es sino una alegría acompañada dela idea de una causa exterior (de la causa exterior que la provoca)" (J. M. Rodríguez Paniagua. "Spinoza y las Meditaciones del Quijote de Ortega y Gasset", en: Atilano Domínguez, Spinoza y España: actas del Congreso Internacional sobre relaciones entre Spinoza y España (Almagro, 5-7 de noviembre 1992), Cuenca, Servicio de Publicaciones de la Universidad de Castilla-La Mancha, 1994, pp. 280-281).

84 Platón, dice Ortega, "descubre el origen de la ciencia en este amor, este Eros, este afán de contemplar las cosas en sí mismas, y no en los juegos de placer y dolor que dentro de nosotros producen. En la Constitución civil o 
impuesta desde fuera por nadie ni por nada. La lleva dentro de sí,

es la raíz misma de su constitución. Dentro de su pecho se levanta perpetuamente una inmensa ambición de claridad -como Goethe, haciéndose un lugar en la hilera de las altas cimas humanas, cantaba: Yo me declaro del linaje de ésos Que de lo oscuro hacia lo claro aspiran. Y a la hora de morir, en la plenitud de un día, cara a la primavera inminente, lanza en un clamor postrero un último deseo, la última saeta del viejo arquero ejemplar: ¡Luz, más luz! Claridad no es vida, pero es la plenitud de la vida. ¿Cómo conquistarla sin el auxilio del concepto? Claridad dentro de la vida, luz derramada sobre las cosas es el concepto. Nada más. Nada menos. Cada nuevo concepto es un nuevo órgano que se abre en nosotros sobre una porción del mundo, tácita antes e invisible. El que os da una idea os aumenta la vida y dilata la realidad en torno vuestro. Literalmente exacta es la opinión platónica de que no miramos con los ojos, sino al través o por medio de los ojos; miramos con los conceptos -véase el diálogo Teetetos, dice Ortega-. Idea en Platón quería decir punto de vista ${ }^{85}$.

La filosofía de Ortega cobija, pues, una teoría del amor que aquél entiende en un primer momento en clave más intelectualista o culturalista donde el concepto predomina al servir de dovela para que todas las cosas del universo entren en conexión evitando así la dispersión:

Las cosas como impresiones son fugaces, huideras, se nos van de entre las manos, no las poseemos. Al atar el concepto unas con otras, las fija y nos las entrega prisioneras. Platón dice que las impresiones se nos escapan si no las ligamos con la razón, como, según la leyenda, las estatuas de Demetrios huían nocturnamente de los jardines si no se las ataba ${ }^{86}$.

Recordemos que Platón ve en el eros, como subraya Ortega, "un ímpetu que lleva a enlazar las cosas entre sí; es -dice- una fuerza unitiva y es la pasión de la síntesis. Por esto, en su opinión, la filosofía, que busca el sentido de las cosas, va inducida por el eros. La meditación es ejercicio erótico. El concepto, rito amoroso"87.

Y lo que trata de hacer finalmente Ortega es proyectar su teoría del amor intelectual (de inspiración spinoziana) que impulsa el concepto o intelecto en lo que denomina el problema de España. Así dice lo siguiente:

República pone al amante de la verdad -filósofos-, formando una clase especial dentro del linaje de los curiosos -filotheamones-, de los amigos de mirar y cuando busca un nombre expresivo para la ciencia, no logra hallar otro más exacto que «teoría», visión, contemplación. Los últimos fundamentos de la verdad, en fin, llámanse en Platón «Ideas», es decir, intuiciones, puntos de vista" (Renán, OC, II, 36).

85 Meditaciones del Quijote, OC, I, 788-789.

86 Ibíd., p. 784. Dice Ortega: "De suerte que, si devolvemos a la palabra percepción su valor etimológico-donde se alude a coger, apresar- el concepto será el verdadero instrumento u órgano de la percepción y apresamiento de las cosas. Agota, pues, su misión y su esencia, con ser no una nueva cosa, sino un órgano o aparato para la posesión de las cosas. Muy lejos nos sentimos hoy del dogma hegeliano, que hace del pensamiento substancia última de toda realidad. Es demasiado ancho el mundo y demasiado rico para que asuma el pensamiento la responsabilidad de cuanto en él ocurre. Pero al destronar la razón, cuidemos de ponerla en su lugar. No todo es pensamiento, pero sin él no poseemos nada con plenitud. Ésta es la adehala que sobre la impresión nos ofrece el concepto; cada concepto es literalmente un órgano con que captamos las cosas. Sólo la visión mediante el concepto es una visión completa; la sensación nos da únicamente la materia difusa y plasmable de cada objeto; nos da la impresión de las cosas, no las cosas" (Meditaciones del Quijote, OC, I, 784).

87 Meditaciones del Quijote, OC, I, 782. 
Conviene a todo el que ame honrada, profundamente la futura España, suma claridad en este asunto de la misión que atañe al concepto. A primera vista, es cierto, parece tal cuestión demasiado académica para hacer de ella un menester nacional. Mas sin renunciar a la primera vista de una cuestión, ¿por qué no hemos de aspirar a una segunda y a una tercera vista? Sería, pues, oportuno que nos preguntásemos: cuando además de estar viendo algo, tenemos su concepto, ¿qué nos proporciona éste sobre aquella visión? ${ }^{88}$.

Párrafos como este justifican que Ortega diga que aunque sus meditaciones no son filosofía, vayan impulsadas por filosóficos deseos, viendo la importancia que concede al concepto, al que denomina rito amoroso que no ha calado en nuestra nación convirtiendo el problema de España en un problema filosófico que atiende a la mengua del espíritu (achabacanamiento nacional por falta de ilustración o cultura moderna científica o racional-conceptual) más que a cualquier otra forma de convivencia u organización.

El concepto nos introduce en la realidad de las cosas y Ortega se pregunta en infinitas ocasiones por esa cosa llamada España al son de la siguiente declaración:

Mi mocedad no ha sido mía, ha sido de mi raza. Mi juventud se ha quemado entera, como la retama mosaica, al borde del camino que España lleva por la historia. Hoy puedo decirlo con orgullo y con verdad. Esos mis diez años jóvenes son mis trojes sólo de angustias y esperanzas españolas ${ }^{89}$.

En fin, al pensamiento de Platón, Ortega añade la célebre expresión spinoziana de "amor intellectualis", si bien es verdad que frente a Spinoza que dice que "el amor intelectual de Dios, que nace del tercer género de conocimiento, es eterno"90, el pensador español nos habla de un amor intelectual circunstancial de signo cultural y/o conceptual que es el que confiere una mayor claridad al dotarnos del sentido físico y moral de las $\operatorname{cosas}^{91}$ de nuestra más inmediata realidad. Esto es a lo que Ortega aspira en relación a España como nación, a cuyo problema, que es especialmente de índole cultural, se ha propuesto encontrar una solución. La idea de cultura es una de las ideas principales que Ortega utiliza para elaborar el discurso filosófico de Meditaciones del Quijote.

Si para Spinoza Deus sive natura (la identidad de Dios y la naturaleza) ${ }^{92}$, para Ortega, Deus sive Cultura, Dios es la Humanidad en la Cultura que el filósofo madrileño identifica con las grandes construcciones culturales:

$88 \quad$ Ibíd., pp. 782-783.

89 Personas, obras, cosas (1916), OC, II, 9.

90 B. de Spinoza. Ética demostrada según el orden geométrico, edición preparada por Vidal Peña, Madrid, Editorial Nacional, 1984, p. 382.

91 Dice Ortega: "Jamás nos dará el concepto lo que nos da la impresión, a saber: la carne de las cosas. Pero esto no obedece a una insuficiencia del concepto, sino a que el concepto no pretende tal oficio. Jamás nos dará la impresión lo que nos da el concepto, a saber: la forma, el sentido físico y moral de las cosas" (Meditaciones del Quijote, OC, I, 784). El concepto es “el órgano normal de la profundidad” (Meditaciones del Quijote, OC, I, 778).

92 Ortega hace referencia a esta célebre expresión de Spinoza en el contexto de sus críticas a lo subjetivo: "Lo subjetivo, en suma, es el error. Un espíritu, dice Ortega en 1909, cuyas operaciones todas crearan verdad objetiva carecería de subjetividad, de morada interior: sería idéntico a la Naturaleza, y por corresponder a Dios esa absoluta veracidad, viose obligado Spinoza a identificarlo con aquélla y exclamar: Natura sive Deus: la Naturaleza o, lo que es lo mismo, Dios... De donde sacamos la grave enseñanza de que Dios es el ser sin intimidad" (Renán, OC, II, 33). 
Dios, dice Ortega en La Teología de Renán (1910), queda disuelto en la historia de la humanidad; es inmanente al hombre: es, en cierto modo, el hombre mismo padeciendo y esforzándose en servicio de lo ideal. Dios, en una palabra, es la cultura. «Tú eres mi mejor yo», canta una vez Shelley a la mujer que inspira sus canciones; podría decirse que Dios es el conjunto de las acciones mejores que han cumplido los hombres: el Partenón y el Evangelio, Don Quijote y la mecánica de Newton, la Revolución francesa y la Historia Romana de Mommsen, las cooperativas de consumo y el régimen parlamentario. Dios es lo mejor del hombre, lo que le enorgullece, lo que intensifica su energía espiritual, la herencia científica y moral acumulada lentamente en la historia ${ }^{93}$.

En Meditaciones del Quijote, Ortega concibe la cultura hermenéuticamente o como labor de interpretación o exégesis de la vida: "Toda labor de cultura es, dice Ortega, una interpretación -esclarecimiento, explicación o exégesis- de la vida. La vida es el texto eterno, la retama ardiendo al borde del camino donde Dios da sus voces. La cultura -arte o ciencia o política- es el comentario, es aquel modo de la vida en que, refractándose ésta dentro de sí misma, adquiere pulimento y ordenación"94.

Esta cultura hermenéutica del amor como afán de comprensión que Ortega utiliza para diseñar su filosofía en su primera gran obra incorpora asimismo una perspectiva estimativa o relativa al orden de los valores a la que ya hicimos mención en nuestra crítica desde Ortega a la Restauración.

En el contexto de esta corriente estimativa que la obra de Ortega asimila, y en relación al tema del amor desde la fenomenología, no podemos dejar de mencionar a otro de los autores que Ortega leyó con más intensidad, a saber: Max Scheler ${ }^{95}$. La filosofía de los valores o estimativa en el pensamiento o reflexión sobre el amor por parte de Ortega conecta con la filosofía de los valores y la fenomenología del amor/odio de Max Scheler. Algunas obras de Scheler aparecen entre las lecturas del filósofo español. En su biblioteca personal encontramos en alemán, con fecha de 1913, Zur Phänomenologie und Theorie der Sympathiegefühle und von Liebe und Hass Mit einem Anhang über den Grund zur annahme der Existenz des fremden Ich (Halle: Max Niemeyer, 1913. La fenomenología y la teoría de la simpatía y sentimientos de amor y odio...). Obra en que Ortega muy probablemente se inspiró.

\footnotetext{
La Teología de Renán, OC, I, 334.

Meditaciones del Quijote, OC, I, 788.

95 En Gramática de los sentimientos. Lo emocional como fundamento de la ética de Max se compilan toda una serie de textos, de los que buena parte se ocupan del fenómeno del amor y el odio: "Sentir y sentimientos" (1916), "Sobre la fenomenología del amor y el odio" (1913), "Ordo amoris" (1916), "Formalismo y apriorismo"(1913), "Sobre la esencia de la filosofía y de la condición moral del conocimiento filosófico"(1917) y "Sobre el fenómeno de lo trágico"(1914) componen aquel trabajo recopilatorio. En todos estos textos, Max Scheler recupera algunas importantes ideas ya expuestas anteriormente en Ética. Nuevo ensayo de fundamentación de un personalismo ético (1913), y también en Esencia y formas de la simpatía (1913). Sus magníficas reflexiones fenomenológicas sobre el amor y el odio es de lo más logrado de su pensamiento, y que Max Scheler resume en el capítulo titulado "Sobre la fenomenología del amor y el odio", extraído del trabajo Wesen und Formen der Sympathie (Esencia y formas de la simpatía). En el tomo V de sus Obras completas, en nota a pie de página, podemos comprobar como nos sugiere Ortega consultar la gran obra de Scheler: Wesen und Formen der Sympathie, 1923 (Véase Estudios sobre el amor, OC, V, 514, n.). Lo mismo ocurre en Sobre la expresión, fenómeno cósmico, OC, II, 682, n. También cita Ortega la obra mentada de Scheler en La percepción del prójimo, OC, VI, 219, n. Ortega recurrirá a Scheler a propósito de la distinción entre "amor sexual" e "instinto sexual" que no puede ser objeto de este trabajo: "Nunca se ha distinguido suficientemente - tal vez con la sola excepción de Scheler- entre el «amor sexual» y el «instinto sexual», hasta el punto de que cuando se nombra aquél se suele entender éste" (Estudios sobre el amor, OC, V, 473).
} 
Los estudios sobre el amor de Max Scheler aparecen especialmente en Gramática de los sentimientos. Lo emocional como fundamento de la ética (recopilación de textos de Max Scheler de entre 1913 y 1917).

Amar y odiar, constituyen, afirma Scheler, el estadio superior de nuestra vida intencional emocional. El amor y el odio son actos en los que el reino de los valores (a cuya existencia se halla ligado también el preferir), que en cada caso es accesible al sentir de un ser, sufre una ampliación o, por el contrario, un estrechamiento ${ }^{96}$. Por su parte, Ortega nos dice que amor y odio poseen la misma dirección, puesto que son centrífugos. En ellos la persona va hacia el objeto; pero dentro de esa única dirección llevan distinto sentido, opuesta intención. En el odio se va hacia el objeto, pero se va contra él; su sentido es negativo. En el amor se va también hacia el objeto, pero se va en su favor: "Amor es corazón junto a corazón: concordia; odio es discordia, disensión metafísica, absoluto no estar con lo odiado" ${ }^{97}$.

En el pensamiento de ambos autores encontramos una metafísica del amor que en la filosofía de Ortega se extiende hasta su madurez intelectual. Cuando el otro corresponde, afirma Ortega en Estudios sobre el amor (1941), "sobreviene un periodo de unión transfusiva, en que cada cual traslada al otro las raíces de su ser y vive piensa, desea, actúa-, no desde sí mismo, sino desde el otro. También aquí se deja de pensar en el amado, de puro tenerlo dentro" ${ }^{98}$. Este asunto es planteado por Scheler en términos muy parecidos -aunque existen diferencias, al partir ambos autores de circunstancias y presupuestos filosóficos distintos que no pueden ser objeto, por una cuestión de espacio, de este artículo de investigación- cuando dice que en el amor, acto primigenio, un ente, sin dejar de ser el ente limitado que es, se abandona a sí mismo, "para formar parte y participar en otro ser como ens intentionale, sin que se convierta cada uno en una parte real del otro (...). El ser humano es, antes de ser un ens cogitans o un ens volens, un ens amans"99.

Max Scheler, remite como Ortega a Platón, afirmando que el amor es un movimiento en dirección hacia "el ser-más-elevado de los valores"100, que él sitúa en el marco más amplio de lo que llama ordo amoris recto y verdadero, del que dice que es "la idea de un reino, sólidamente objetivo e independiente de los seres humanos, de las disponibilidades, ordenadas, de ser amadas todas las cosas -o sea, de algo que sólo podemos conocer, no poner, crear, hacer-" ${ }^{\prime 101}$. El amor es, por

96 Véase M. Scheler. "Sentir y sentimientos", en Gramática de los sentimientos. Lo emocional como fundamento de la ética, Barcelona, Editorial Crítica, 2002, p. 36.

97 Estudios sobre el amor, O.C, V, 460-462. El amor es creación y el odio es destrucción, o como dice Scheler: "el odio es destructor en el sentido más estricto de la palabra, puesto que destruye (...) efectivamente los valores más elevados y puesto que tiene como consecuencia que la mirada del preferir cognitivo y del sentir sean obtusos y ciegos para estos valores: "¡Porque los destruye (para esta esfera), por eso se hacen imposibles de ser sentidos!" (Véase M. Scheler. "Sobre la fenomenología del amor y el odio", en Gramática de los sentimientos. Lo emocional como fundamento de la ética, Barcelona, Editorial Crítica, 2002, p. 53).

98 Estudios sobre el amor, OC, V, 488. Estrictamente hablando el amor es, según Ortega, pura actividad sentimental hacia un objeto, que puede ser cualquiera, persona o cosa. En cuanto actividad sentimental queda el amor, por una parte, separado de todas las funciones intelectuales - percibir, atender, pensar, recordar, imaginar-; por otra parte, del deseo con que a menudo se le confunde: "Nacen, sin duda, del amor deseos; pero el amor mismo no es desear" (Estudios sobre el amor, O.C, V, 477).

99 M. Scheler. "Ordo amoris", en Gramática de los sentimientos. Lo emocional como fundamento de la ética, Barcelona, Editorial Crítica, 2002, p. 77.

100 M. Scheler. "Sobre la fenomenología del amor y el odio", en Gramática de los sentimientos. Lo emocional como fundamento de la ética, Barcelona, Editorial Crítica, 2002, p. 52.

101 Scheler, M.: “Ordo amoris”, en op.cit., p. 69. 
tanto, movimiento hacia lo que consideramos con alguna perfección, es decir, hacia algo dotado de algún valor superior, coincidiendo en ello con Ortega, que dice en Meditaciones del Quijote que "en el orden de los valores, son los valores máximos la unidad de medida. Sólo comparándolas con lo más estimable quedan justamente estimadas las cosas. Conforme se van suprimiendo en la perspectiva de los valores los verdaderamente más altos, se alzan con esta dignidad los que les siguen. El corazón del hombre no tolera el vacío de lo excelente y supremo"102. La estimación por los valores superiores es estimación por la perfección, siendo para Ortega y Scheler el amor no otra cosa que amor a la perfección de lo amado. Coinciden pues Ortega y Scheler en que el amor es afán de perfección del ser amado, "anhelo de engendrar en lo perfecto", como también lo fue para los moralistas, pensadores y poetas de la antigüedad clásica.

El amor, afirma Max Scheler, inspirándose, como Ortega, en El Banquete de Platón, no es otra cosa que una aspiración o tendencia de lo inferior a lo superior, de lo imperfecto a lo perfecto, de lo informe a la forma, de la apariencia (no ser) a la esencia (el ser) ${ }^{103}$.

Desde la metafísica platónica del amor, ambos pensadores consideran que éste es anhelo de engendrar en la belleza. En el vocabulario platónico, "belleza" es el nombre concreto de lo que más genéricamente nosotros solemos llamar perfección:

Formulada con alguna cautela, pero ateniéndonos rigorosamente al pensamiento de Platón, su idea es ésta: en todo amor reside un afán de unirse el que ama a otro ser que aparece dotado de alguna perfección. Es, pues, un movimiento de nuestra alma hacia algo en algún sentido excelente, mejor, superior. Que esta excelencia sea real o imaginaria no hace variar en lo más mínimo el hecho de que el sentimiento erótico -más exactamente dicho, el amor sexual- no se produce en nosotros sino en vista de algo que juzgamos perfección. Ensaye el lector representarse un estado amoroso -de amor sexual- en que el objeto no presente a los ojos del que ama ningún haz de excelencia, y verá cómo es imposible. Enamorarse es, por lo pronto, sentirse encantado por algo (ya veremos con algún detalle qué es esto del «encantamiento»), y algo sólo puede encantar si es o parece ser perfección. No quiero decir que el ser amado parezca íntegramente perfecto -éste es el error de Stendhal. Basta que en él haya alguna perfección, y claro es que perfección en el horizonte humano quiere decir, no lo que está absolutamente bien, sino lo que está mejor que el resto, lo que sobresale en un cierto orden de cualidad; en suma: la excelencia ${ }^{104}$.

102 Meditaciones del Quijote, OC, I, 771.

103 Véase M. Scheler. El resentimiento en la moral, traducción de José Gaos, Madrid, Caparrós Editores, 1998, pp. 62 y ss.

104 Estudios sobre el amor, O.C, V, 473s. Ortega, en Estudios sobre el amor (1941), critica la "teoría de la cristalización de Stendhal", aun admirando su figura: "Conocida es la metáfora que proporciona a Stendhal el vocablo «cristalización » para denominar su teoría del amor (...). La imagen real de una mujer cae dentro del alma masculina y poco a poco se va recamando de superposiciones imaginarias, que acumulan sobre la nuda imagen toda posible perfección. Siempre me ha parecido esta ilustre teoría de una superlativa falsedad. Tal vez lo único que de ella podemos salvar es el reconocimiento implícito -ni siquiera declarado- de que el amor es, en algún sentido y de alguna manera, impulso hacia lo perfecto. Por ello cree Stendhal necesario suponer que imaginamos perfecciones. Sin embargo, él no se ocupa de este punto; lo da por supuesto, lo deja a la espalda de su teoría y ni advierte siquiera que es el momento más grave, más profundo, más misterioso del amor. La teoría de la «cristalización» se preocupa más bien de explicar el fracaso del amor, la desilusión de fallidos entusiasmos; en suma, el desenamoramiento y no el enamoramiento" (Estudios sobre el amor, O.C, V, 472). Esta teoría califica "al amor de constitutiva ficción. No es que el amor yerre a veces, sino que es, por esencia, un error. Nos enamoramos cuando sobre otra persona nuestra imaginación proyecta inexistentes perfecciones. Un 
Para Platón la belleza no significaba propiamente perfección de un cuerpo, sino que era el nombre de toda perfección, es decir,

la forma, por decirlo así, en que a los ojos griegos se presentaba todo lo valioso. Belleza era optimidad (...). Amor es afán de engendrar en la belleza (...)-decía Platón. Engendrar, creación de futuro. Belleza, vida óptima. El amor implica una íntima adhesión a cierto tipo de vida humana que nos parece el mejor y que hallamos preformado, insinuado en otro $\operatorname{ser}^{105}$.

Resumiendo, el amor es, por tanto, movimiento hacia lo que consideramos con alguna perfección, es decir, hacia algo dotado de algún valor superior o supremo. En el amor, tanto para Scheler como para Ortega, se ilumina el valor superior. El acto del amor desempeña el papel verdaderamente descubridor en nuestro percibir los valores, que, dice Scheler, no son creados ni aniquilados. Existen con independencia de la organización de determinados seres espirituales. Representa el amor un movimiento, pues, en el curso del cual relampaguean y resplandecen valores nuevos y superiores ${ }^{106}$.

\section{Resultados de la investigación y breve conclusión}

Como conclusión de este trabajo de investigación, y en lo que sería un compendio de los resultados alcanzados, tenemos que decir, en primer lugar, que en Ortega

día la fantasmagoría se desvanece, y con ella muere el amor (...). La teoría de la «cristalización » es idealista porque hace del objeto externo hacia el cual vivimos una mera proyección del sujeto (...). La teoría de la «cristalización» es pesimista. En ella se tiende a demostrar que lo que consideramos funciones normales de nuestro espíritu no son más que casos especiales de anormalidad" (Véase para ampliar esta crítica de Ortega a la "teoría de la cristalización" de Stendhal, Estudios sobre el amor, O.C, V, 466 y ss).

105 Estudios sobre el amor, O.C, V, 506. Bien es verdad que Ortega en Estética en el tranvía (1916) -aunque el origen de este posicionamiento está ya en Meditaciones-, deja claro, de forma muy explícita, su distanciamiento del idealismo/racionalismo del filósofo griego a este respecto. Su posición es, por tanto y en cierto modo, ambivalente en relación a Platón, pues admira su filosofía y su teoría del amor como afán de conexión y anhelo de perfección, si bien para Ortega el amor a la perfección es amor al ideal que extraemos de la realidad de las cosas y no subjetivamente o idealísticamente de nuestras cabezas. Dice Ortega: "La antigua psicología supone que el individuo posee un previo ideal de belleza, en este caso, un ideal de rostro femenino, el cual aplica sobre el semblante real que está mirando. El juicio estético consistiría simplemente en la percepción de la coincidencia o discrepancia entre uno y otro. Esta teoría, procedente de la metafísica platónica, se ha inveterado en la estética y vierte en ella su originario error. El ideal, como la idea en Platón, viene a ser una unidad de medida, preexistente y aparte de las realidades, con la cual medimos éstas. Semejante teoría es una construcción, una invención oriunda del genial afán helénico tras la unidad (...). No hay un modelo único y general (...). Lejos de saber cuál sea la belleza suma en la mujer, el hombre la busca perpetuamente desde su mocedad a su decrepitud. (...).Cada mujer que por vez primera vemos suscita en nosotros la suprema esperanza de que es ella acaso la más bella". Ortega tiene claro que "no hallo en mí ese arquetipo y modelo único de belleza femenina (....). Venimos, pues, al convencimiento de que el modelo no es uno para todos, ni siquiera típico. Cada fisonomía suscita, como en mística fosforescencia, su propio, único, exclusivo ideal. Cuando Rafael dice que él pinta no lo que ve, sino «una certa idea che mi viene in mente», no se entienda la idea platónica que excluye la diversidad inagotable y multiforme de lo real. No; cada cosa al nacer trae su intransferible ideal". Dondequiera, dice Ortega, "nos es fecunda esta idea, que descubre en la realidad misma, en lo que tiene de más imprevisible, en su capacidad de innovación ilimitada, la sublime incubadora de ideales, de normas, de perfecciones". Y el amor a la realidad en su diversidad no es otra cosa que "Amor a la multiplicidad de la vida" (Estética en el tranvía, OC, II, 176 y ss).

106 Véase M. Scheler. "Sentir y sentimientos", en Gramática de los sentimientos. Lo emocional como fundamento de la ética, Barcelona, Editorial Crítica, 2002, pp. 37 y ss. 
encontramos una teoría del amor que recorre toda su obra, desde su mocedad hasta su madurez intelectual. Su reflexión sobre el amor -que Ortega convierte en un problema filosófico siguiendo toda una tradición- acusa sensiblemente los cambios en su pensamiento desde los inicios de su producción intelectual, cuando Ortega marcha a Alemania, que para él "es precisamente la nación cuya influencia en la dirección moral e intelectual nuestra habrá de sernos más fecunda"107.

En un primer periodo, Ortega expone, a mi juicio, las virtudes del idealismo de la modernidad desde el neokantismo alemán que afirma la prioridad de la norma, la ciencia y la moral. Desde 1912 sino antes, Ortega viene anunciando, no obstante, la prioridad de lo vital como ámbito integral frente a todo lo demás, la cultura, la norma o la ley científico moral...., una vez que leyendo fenomenología con su idea del "mundo de la vida" o Lebenswelt, reconoce las insuficiencias del idealismo y exclusivismo del discurso filosófico de la Modernidad donde el amor lo era al ideal en la mente del sujeto (subjetivismo como enfermedad del siglo XIX), y no amor al ideal en la realidad de las cosas de nuestra más inmediata circunstancialidad.

Del amor al ideal que en la modernidad juzgaba las cosas desde la norma y por su utilidad y que localizábamos en el reino del deber ser moral, transitamos en Meditaciones del Quijote, obra que ha vehiculado nuestra reflexión en este artículo de investigación, al amor al ideal pero inserto éste en la realidad vital o en el ámbito de lo que es pues de eso es de lo que se trata a partir de 1914, a saber "de declarar lo que es y no lo que debe ser", como así ocurría años atrás cuando Ortega se sumió en el idealismo de la ciencia, la cultura y la moral en lo que yo mismo denomino su germanófila mocedad ${ }^{108}$.

A partir de ahora, desde 1914 y en adelante, se impone la realidad aunque en ella encontramos, como asimismo ha puesto de relieve el profesor Cerezo Galán en "Cervantes, El Quijote y la aurora de la razón vital"109, un eje de virtualidad, poético o ideal: "El realismo nos invita, dice Ortega en 1925, a que transformemos la realidad según nuestras ideas; pero a la vez, a que pensemos nuestras ideas en vista de la realidad, a que extraigamos el ideal, no subjetivamente de nuestras cabezas, sino objetivamente de las cosas"110.

El amor al ideal que heredamos de la modernidad, Ortega no lo abandona, pues "como Hegel sostenía, y recuerda Ortega, en la evolución del pensamiento toda destrucción es una superación y toda superación es una conservación"111, pero Ortega le aplica un severo correctivo, al entender que el amor es amor a la perfección de lo amado, a la perfección de las cosas amadas del mundo vital circunstancial tratando de romper su realidad "para, como dice él mismo, hacer posible su perfección" o lograr su máximo esplendor. Salvarlas - las cosas, se entiende-, es salvarnos a nosotros mismos, de ahí que la reabsorción de la circunstancia sea el destino concreto del hombre: "Mi salida natural hacia el universo se abre por los puertos del Guadarrama

107 Notas de Berlin, O.C, I, 51.

108 Es cierto, como dice Jordi Gracia en su biografía sobre Ortega, que en la formación de éste está activamente integrada la cultura francesa -Renán, Charles Maurras o Barrés- (Véase J. Gracia. José Ortega y Gasset, Madrid, Taurus, 2014, p. 101), pero no es menos verdad que hay un predominio claro en su pensamiento de mocedad de la cultura y la ciencia alemanas como núcleo de las europeas.

109 P. Cerezo Galán. “Cervantes y El Quijote en la aurora de la razón vital”, Revista de Occidente, n 312, pp. 5-34.

110 Entreacto polémico, O.C, III, 800.

111 Sistema de la psicología, OC, VII, 476. La nueva idea que supera a la antigua "la lleva en sí perpetuamente (...). Al revés que en la generación biológica en la ideológica las ideas recién nacidas llevan en su vientre a sus madres" (Ibíd., p. 476). 
o el campo de Ontígola. Este sector de realidad circunstante forma la otra mitad de mi persona: sólo al través de él puedo integrarme y ser plenamente yo mismo (...). Yo soy yo y mi circunstancia, y si no la salvo a ella no me salvo yo. Benefac loco illi quo natus es, leemos en la Biblia"112.

Yo y mundo, desde la programática fecha de 1914 se muestran en conexión/ interacción, al fomento de las cuales contribuye el amor, frente a todo posible odio o aversión. Yo y mundo serían como los Dii consentes, los dioses unánimes, parejas de divinidades antiguas que nacían y morían juntas, inseparables pero al mismo tiempo irreductibles. Aunque la primera parte de su célebre sentencia relativa a la interacción entre el yo y su circunstancia ha sido objeto de una inagotable labor hermenéutica en los círculos orteguianos, no es menos cierto que lo que luego añade Ortega no se puede desdeñar, pues dice que: "en la escuela platónica se nos da como empresa de toda cultura, ésta: «salvar las apariencias», los fenómenos. Es decir, buscar el sentido de lo que nos rodea"113. Salvar las apariencias en aquello que late o se oculta tras ellas en su dimensión de idealidad, poética o virtual, es a lo que Ortega se refiere con la idea de "sentido" de la realidad.

La búsqueda del sentido o logos extrayéndolo de lo "ilógico" o todavía sin inteligibilidad, no la realiza Ortega desde la frialdad del juicio como ordenaba la Modernidad y especialmente Kant, sino desde el sentimiento y la emoción, desde el amor que también es contemplación (amor intellectualis dice Ortega, resucitando el lindo nombre que usó Spinoza) pero no desde un horizonte filosófico racionalista -al que se aproximaba en su inicios germanófilo neokantianos-, sino raciovitalista y en un contexto no europeo sino nacional atendiendo como hace Ortega al problema que más le preocupó desde su mocedad: El problema de España, al que dedicó su filosofía o al menos buena parte de la misma desde su juventud en Alemania como eje de la modernidad.

Ortega en Meditaciones del Quijote, retira el juicio sobre las cosas, sobre lo que deben ser y no son para dejar paso al amor que trata de comprenderlas desde lo que son: "Cada día, dice Ortega en 1914, me interesa menos sentenciar: a ser juez de las cosas, voy prefiriendo ser su amante" $" 114$.

Esta posición ético amorosa y fenomenológica del amor como afán integral de comprensión de las cosas más nimias y en circunstancia para conducirlas a su máximo esplendor, plenitud de significado o perfección, desplaza al conocimiento de las mismas desde el juicio que dicta la fría razón. No es el juicio sino el amor el nervio divino del raciovitalismo del filósofo español. El amor a la perfección del mundo de la realidad también requiere de la razón, pero de la razón vital que hace del concepto, como dijimos, un instrumento, "no para sustituir la espontaneidad vital, sino para asegurarla" 115 en un régimen de salud que evita, como ya dijimos, toda forma de inestabilidad o excentricidad.

En Meditaciones del Quijote, hablaríamos pues de una especie de "intelectualismo"116 culturalista/conceptualista hermenéutico o interpretativista pero al servicio de la realidad de la vida-cuyo primado a partir de 1914 se intensifica- que

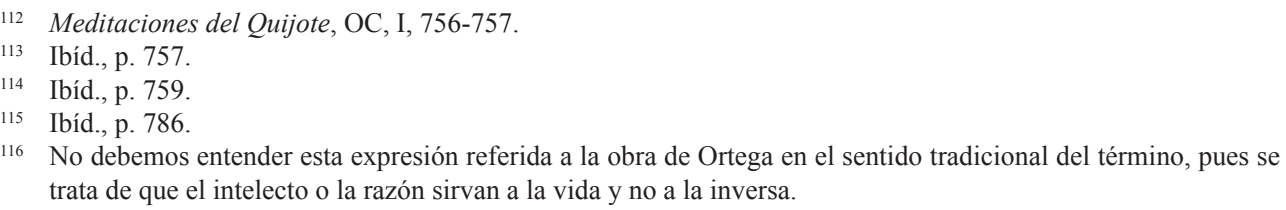


comprende tanto al yo, como también la idea de circunstancia o mundo social y que Ortega convierte en una teoría del amor (amor intelectual) buscando su perfección, es decir, la perfección/salvación de la circunstancia nacional.

Podemos concluir este trabajo de investigación afirmando que el teórico español hace suya, como ha quedado suficientemente claro, la célebre expresión spinoziana amor intellectualis $^{117}$-que aparece como descripción platonizante del conocimientoque pone, junto a la filosofía del amor de Sócrates y especialmente de Platón ${ }^{118}$, la teoría de los valores (o estimativa) y la idea del ordo amoris de Max Scheler, así como la reflexión de Nietzsche sobre el resentimiento y/o el rencor, al servicio de la comprensión de la circunstancia y/o situación cultural e histórico-social -léase realidad- de nuestra nación. Pues el afecto hacia ella es, dice Ortega, "el más vivo que encuentro en mi corazón" "119.

\section{Referencias bibliográficas}

Berges, C. “Stendhal, Ortega y el amor”. Insula: revista de letras y ciencias humanas, n 438439, 1983, p. 5.

Campomar Fornieles, M. "Victoria Ocampo en la cultura del amor de Ortega y Gasset". Revista de Estudios Orteguianos, n ${ }^{\circ} 3$, 2001, pp. 209-290.

Carchidi, L. "Estudios sobre el amor. Radici letterarie e filosofiche del tema dell'amore in José Ortega y Gasset". Atti del XX Convegno [Associazione Ispanisti Italiani] / Domenico Antonio Cusato, Loretta Frattale (Coord.), Vol. 1, 2002 (La penna di venere: escritture dell'ammore nelle culture iberiche), pp. 71-80.

Cerezo Galán, P. “Cervantes y El Quijote en la aurora de la razón vital”. Revista de Occidente, $\mathrm{n}^{\mathrm{o}}$ 312, 2007, pp. 5-34.

De Salas, J. “Amor Intellectualis. Spinoza en la configuración de la obra de Ortega y algunas posibles fuentes de la obra temprana del filósofo español”. En Atilano Domínguez (Coord.): Spinoza y España, Actas del Congreso Internacional sobre Relaciones entre Spinoza y España, Ediciones de la UCLM, 1994, pp. 285-293.

Ferreiro Lavedán, M. I. y González Alcázar, F. (ed.). "Notas de trabajo de Meditaciones del Quijote". Revista de Estudios Orteguianos, n. 28, 2014, pp. 17-41.

117 Ortega proyecta la expresión amor intellectualis Dei, como él mismo la denomina, al ámbito de la cultura (Dios es la Cultura, con mayúsculas) y Spinoza nos habla del amor Dei intellectualis como amor a Dios, es decir, como amor al conocimiento de Dios como supremo bien del alma, siendo su suprema virtud, "la de conocer a Dios" (B. de Spinoza, Ética demostrada según el orden geométrico, edición preparada por Vidal Peña, Madrid, Editorial Nacional, 1984, p. 291), o sea, “entender las cosas según el tercer género de conocimiento (por la Proposición 25 de esta Parte), y esa virtud es tanto mayor cuanto más conoce el alma las cosas conforme a ese género (por la proposición 24 de esta Parte)" (B. de Spinoza, Ética demostrada según el orden geométrico, edición preparada por Vidal Peña, Madrid, Editorial Nacional, 1984, p. 378). Dios en la naturaleza o la naturaleza en Dios. Ambos, Ortega y Spinoza, consideran aquélla fórmula (amor Dei intellectualis o amor intellectualis $\mathrm{Dei}$ ), cada uno con sus particularidades, como fuente de amor como conocimiento superior, que Ortega vincula principalmente al concepto y Spinoza a la razón y especialmente a lo que denomina ciencia intuitiva cuando en su Ética nos habla de los grados o géneros del conocimiento que se suceden hasta alcanzar el conocimiento de Dios (Véase B. de Spinoza, Ética demostrada según el orden geométrico, edición preparada por Vidal Peña, Madrid, Editorial Nacional, 1984, pp. 157 y ss y 381 y ss).

118 Platón -que fue un referente para el filósofo madrileño en esta cuestión- constituyó, como ha quedado suficientemente constatado, una auténtica cantera de ideas para Ortega.

119 Meditaciones del Quijote, OC, I, 747. 
Ferreiro Lavedán, M. I. y Carriazo, J.R (ed.). "Notas de trabajo sobre Cervantes y El Quijote", Revista de Estudios Orteguianos, n. ${ }^{\circ} 10 / 11$ (2005), pp. 33-75.

Ferreiro Lavedán, M. I. "El amor por lo distinto en la obra de Ortega y Gasset". Razón Española: Revista bimestral de pensamiento, no 133, 2005, pp. 181-202.

Gonzalo Gironés, G. "Hablando con Ortega acerca del amor". Anales Valentinos: revista de filosofía y teología. Vol. 30, nº 60, 2004, p. 289.

González-Sandoval Buedo, J. "Sobre el amor en Ortega". Revista de Estudios Orteguianos, n 22, 2011, pp. 197-228.

Gracia. J. José Ortega y Gasset. Madrid, Taurus, 2014.

Hernández Sánchez, D. (ed.). “Hegel. Notas de trabajo de José Ortega y Gasset”. Fundación José Ortega y Gasset/Abada Editores, 2007.

Husserl. E. Ideas relativas a una fenomenología pura y una filosofía fenomenológica. Libro segundo: investigaciones fenomenológicas sobre la constitución. México, Universidad Nacional Autónoma de México, 1997.

Laín Entralgo, P. "Ciencia, esperanza y amor en el pensamiento de Ortega". Javier San Martin (Coord.): Ortega y la fenomenología: Actas de la I Semana Española de Fenomenología, 1992, pp. 325-338.

Lasaga Medina, J. Las metamorfosis del seductor. Ensayo sobre el mito de Don Juan, Madrid, Síntesis, 2004.

Lasaga Medina, J. Figuras de la vida buena (Ensayo sobre las ideas morales de Ortega y Gasset), Madrid, Enigma Editores, 2006.

Nietzsche, F. Ecce homo, traducción de Andrés Sánchez Pascual, Madrid, Alianza, 1985.

Nietzsche, F. El Anticristo, traducción, introducción y notas de Andrés Sánchez Pascual, Madrid, Alianza, 1980.

Ortega Y Gasset, J. Obras completas. Madrid, Taurus/Fundación José Ortega y Gasset, 20042010.

Platón. Fedro. Introducción, traducción, notas y comentario de Armando Poratti, Madrid, Akal, 2010.

Platón. El Banquete. Madrid, Tecnos, 2006.

Ramos De La Torre, L. "Vida y salvación desde al amor a las cosas en Claudio Rodríguez y Ortega". Duererías (Ejemplar dedicado a "Brevis e absurda: vita"), n 5, 2005, pp. 108151.

Rodríguez Huéscar. A. "Reflexiones sobre Ortega y la política”. Revista de Occidente, n 72 , 1987, pp. 5-29.

San Martín. J. La fenomenología de Ortega y Gasset. Madrid, Biblioteca Nueva, 2012.

Scheler. M. El resentimiento en la moral. Traducción de José Gaos, edición de José María Vegas, Madrid, Caparrós Editores, 1998.

Scheler. M. Gramática de los sentimientos. Lo emocional como fundamento de la ética, Barcelona, Editorial Crítica, 2002.

Spinoza, B. Ética demostrada según el orden geométrico. Edición preparada por Vidal Peña, Madrid, Editorial Nacional, 1984. 